\title{
Women's participation in disaster relief and recovery
}

Ayse Yonder

Sengul Akcar

Prema Gopalan

Follow this and additional works at: https://knowledgecommons.popcouncil.org/departments_sbsr-pgy

Part of the Civic and Community Engagement Commons, Demography, Population, and Ecology Commons, Politics and Social Change Commons, Women's Health Commons, and the Women's Studies Commons How does access to this work benefit you? Let us know!

\section{Recommended Citation}

Yonder, Ayse, Sengul Akcar, and Prema Gopalan. 2005. "Women's participation in disaster relief and recovery," SEEDS no. 22. New York: Population Council. 


\section{Women's Participation in Disaster Relief and Recovery}

by Ayse Yonder with Sengul Akcar and Prema Gopalan

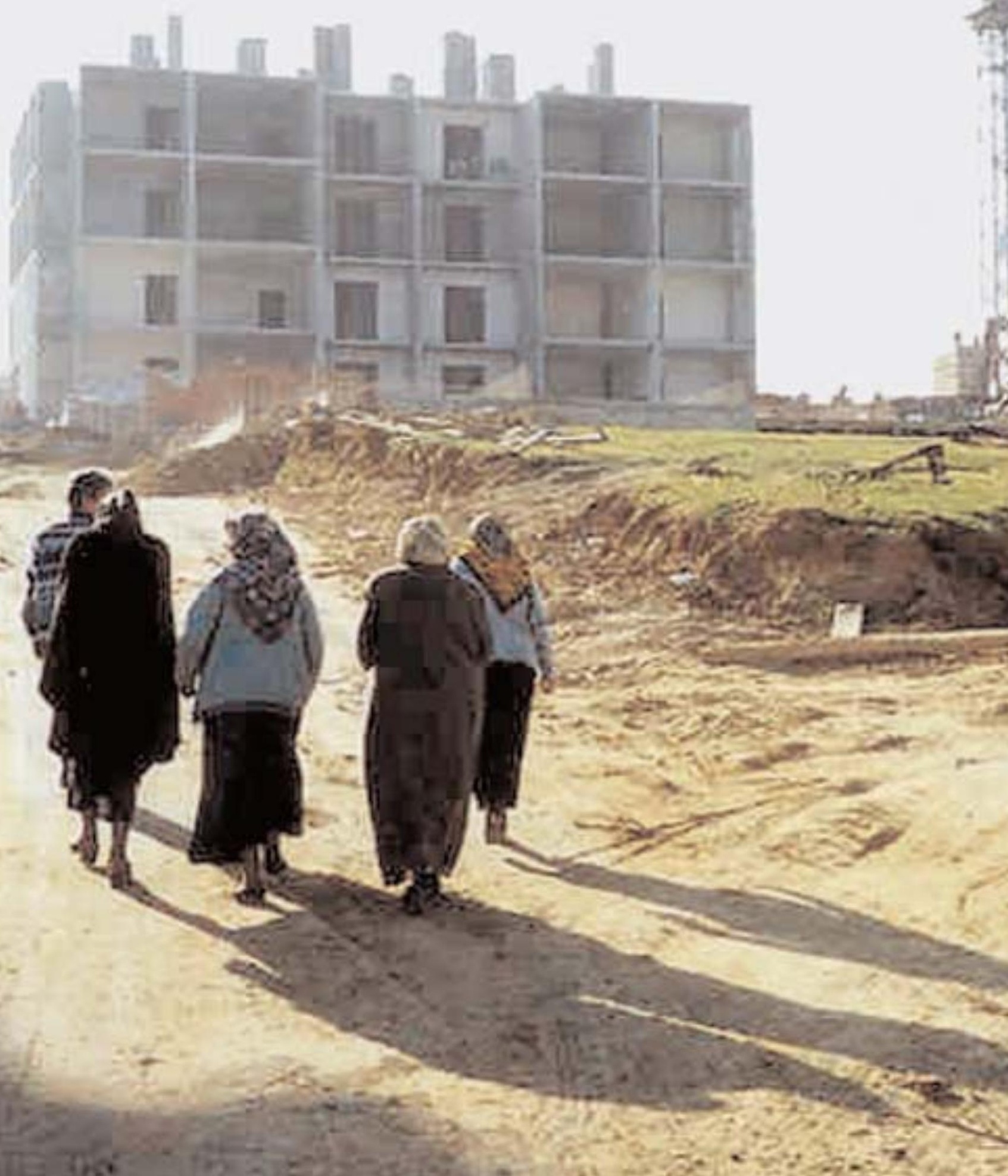




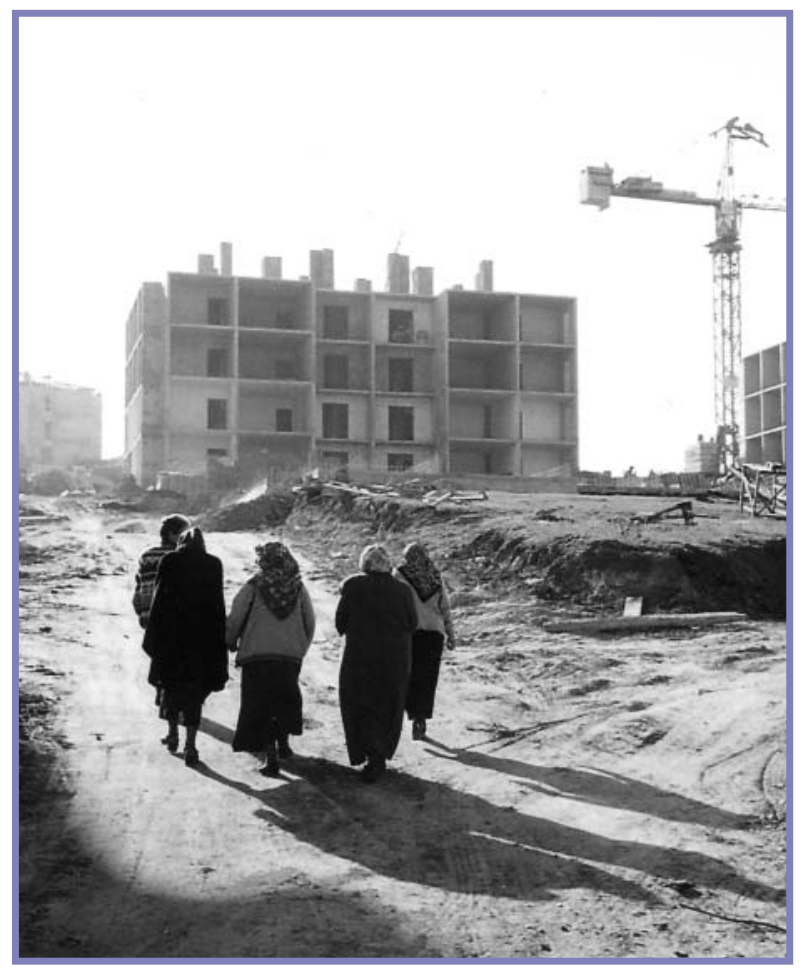

\title{
Women's Participation in Disaster Relief and Recovery
}

\author{
by Ayse Yonder \\ with Sengul Akcar and Prema Gopalan
}

\section{About the Authors}

Ayse Yonder is Professor of City and Regional Planning at the Graduate Center for Planning and the Environment, Pratt Institute in Brooklyn, New York. Her research and publications focus on informal land and housing markets and community development. She started working on postdisaster planning issues after the 1999 Marmara earthquake in Turkey. Sengul Akcar and Prema Gopalan are founding and current executive directors of the two NGOs featured in this edition, KEDV, Istanbul, Turkey, and SSP, Mumbai, India. 


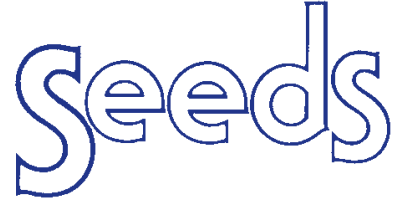

is a pamphlet series developed to meet requests from all over the world for information about innovative and practical program ideas advanced to address the economic roles and needs of low-income women. The pamphlets are designed as a means to share information and to spark new initiatives based on positive experiences from projects that are working to help women generate livelihoods and to improve their economic status. The projects described in this and other issues of SEEDS have been selected because they have served not only to strengthen women's productive roles but also to integrate women into various sectors of social and economic development. All projects documented in the SEEDS series involve women in decisionmaking, organize women locally, and address broader policy issues that affect the economic roles of women.

These reports are not meant to be prescriptive, because every development effort will face different problems and possibilities. Rather, they have been written to describe the history of an idea and its implementation in the hope that the lessons learned can be useful in a variety of settings. They are also being written to bring to the attention of those in decisionmaking positions the vital roles that women play not only in the economies of their individual households but also in the economic life of every nation.

This edition of SEEDS is made possible by support of the Ford Foundation and the Population Council.

\section{(2) Population Council}

The Population Council is an international, nonprofit, nongovernmental organization that seeks to improve the well-being and reproductive health of current and future generations around the world and to help achieve a humane, equitable, and sustainable balance between people and resources. The Council conducts biomedical, social science, and public health research and helps build research capacities in developing countries. Established in 1952, the Council is governed by an international board of trustees. Its New York headquarters supports a global network of regional and country offices.

Population Council, One Dag Hammarskjold Plaza, New York, New York 10017 USA Tel: (212) 339-0500, fax: (212) 755-6052

E-mail: pubinfo@popcouncil.org or seedseditor@gmail.com http://www.popcouncil.org/publications/seeds/seeds.html

Any part of this publication may be copied or adapted to meet local needs without permission from the Population Council, provided that the parts copied are distributed free or at cost (not for profit) and that the source is identified. The Population Council would appreciate receiving a copy of any materials in which the text is used.

Number 22, 2005 ISSN: 073-6833

Copyright (c) 2005 The Population Council, Inc. 


\section{Foreword}

SEEDS is pleased to publish its twentysecond pamphlet: Women's Participation in Disaster Relief and Recovery by Professor Ayse Yonder with Sengul Akcar and Prema Gopalan.

Since this pamphlet was researched and prepared, the world has been reshaped dramatically by natural disasters. In late December 2004, a record-breaking earthquake in the Indian Ocean produced a powerful tsunami killing more than 225,000 people and forcing more than 1.2 million people from their homes in seven Asian countries, in Somalia, and in parts of East Africa (UNICEF 2005). Months later, in July 2005, two successive hurricanes-Dennis and Emily-struck a number of Caribbean islands, Mexico, and the Gulf Coast of the United States. Although the loss of lives was minimal, the economic loss was severe-in excess of five billion dollars (of which half was borne by the Caribbean).

The past three decades of disaster relief and reconstruction efforts bear evidence that the poor are the most vulnerable and the most severely harmed by such events. Yet too little attention has been given to the gender-differentiated effects of natural disasters, that is, women's losses relative to men's, how women's work time and conditions change (both in terms of care-giving and income-generating work), or how disaster-related aid and entitlement programs include or marginalize affected women. Similarly, few practical examples can be found showing how affected low-income women can participate in postdisaster relief and recovery and secure decent housing, livelihoods, and the restoration of basic services for themselves and for their families.

The detailed case studies from three earthquake-stricken areas in India and Turkey that are contained in this SEEDS pamphlet help fill this information gap. They provide examples of how low-income women who have lost everything can form groups and become active participants in the relief and recovery process. Readers learn how women became involved in housing, created businesses, mobilized funds, and provided crucial community services. ${ }^{1}$ The pamphlet also examines the roles that NGOs and government policy and procedures play in facilitating (or impeding) women's involvement.

The structural barriers to reforming disaster aid and recovery programs to respond to the realities and needs of lowincome women are substantial. Yet Women's Participation in Disaster Relief and Recovery indicates that when grassroots women's groups can form networks to transfer and scale up their innovative approaches across many poor communities, these networks can also press for the political and policy change that is required (see SEEDS editions 18 and 20 for other examples). The case studies suggest that as the numbers of disasters increase, donors would do well to invest in the collective organizing power of affected women.

— Sandy Schilen, SEEDS Editor

\footnotetext{
1 The women's groups featured in the pamphlet were documented at particular points in time. They continue to organize and experience gains and losses. For current information on their activities, contact grootsss@gmail.com.
} 


\title{
Women's Participation in Disaster Relief and Recovery
}

\author{
by Ayse Yonder \\ with Sengul Akcar and Prema Gopalan
}

\section{Natural Disasters: \\ A Growing Development Challenge for Poor Women and Their Communities}

Disasters destroy lives, disrupt the social, economic, and political fabric of communities, and can erase decades of development gains, sometimes in a matter of minutes. ${ }^{1}$ Today, despite increased investments and advances in hazard-management technology, human and economic losses from natural disasters are rising annually worldwide. Natural events, common in the developed North as well as the developing South, turn into disasters when conditions of vulnerability (poverty, insecure housing, overcrowding, rapid rates of urbanization) compound the damage (Hewitt 1998; Davis 1999). The combination produces devastating results: Developing countries account for 95 percent of all deaths caused by such disasters and suffer losses that are 20 times greater (as a percent of gross domestic product) than those of industrial countries experiencing similar events (World Bank Group 2005).

Natural disasters are multiplying development problems across the developing world. Table 1 lists some of the recent losses from earthquakes, hurricanes, cyclones, and floods in Asia, the Caribbean, Latin America, and the Middle East. Losses from natural hazards are expected to rise with increasing rates of urbanization and to occur in the largest metropolitan areas of the world, all located in the South (Smith 1996).

At the local level, disasters compound social exclusion and existing vulnerabilities, disproportionately taxing the poor, women, and children. The United Nations Handbook for Estimating the Socioeconomic and Environmental Effects of Disaster (2003) emphasizes that one consequence of disaster "is the decapitalization of women and the reduction of their share of productive activities in the formal and informal sectors." Women are disadvantaged in two ways:

Not only do they sustain direct damages or production losses (housing and means of production), but they also . . lose income when they have to apply themselves temporarily to unpaid emergency tasks and an increased amount of unpaid reproductive work, such as caring for their children when schools are closed... Such reproductive work is usually granted a lower status than paid work. . . . It is also a continuous job . . . which limits women's mobility and can sometimes even prevent them from exercising their rights as citizens. (p. 46)

According to this research, women suffer four types of indirect losses following disasters:

- Loss of productive employment outside the home (domestic, industrial, or commercial);

- Loss of household production and income (including that of the back-

\footnotetext{
${ }^{1}$ Disasters are categorized in two ways: "natural" disasters, a term that traditionally refers to earthquakes, cyclones, volcanic eruptions, floods, landslides, and "man-made" disasters, which include wars, riots, industrial and biological accidents, droughts, famines, and epidemics.
} 
Table 1 A Selective Review of the Losses from Recent Natural Disasters in Developing Countries

\begin{tabular}{llll}
\hline Location (year) & Type of disaster & Estimated deaths & Estimated homeless \\
\hline Sumatra, Indonesia (2004) & Earthquake, tsunami & 174,000 & $500-800,000^{\mathrm{a}}$ \\
Bam, Iran (2003) & Earthquake & 43,000 & 60,000 \\
Gujarat, India (2001) & Earthquake & na & 620,000 \\
Orissa, India (2001) & Cyclone & 10,000 & na \\
China (2000) & Floods & na & 1.5 million \\
Venezuela (1999) & Floods/landslides & 50,000 & na \\
Caribbean coast (1999) & Hurricane & na & $200,000^{\mathrm{b}}$ \\
\hline
\end{tabular}

na $=$ Not available.

Sources: ${ }^{\mathrm{a}}$ British Broadcasting Company (2005); ${ }^{\mathrm{b}}$ United Nations Commission on Human Settlements (UN-Habitat) (2001).

yard economy and of small businesses run by women from their homes);

- Increase in reproductive work; and

- Other economic damage resulting from outstanding debts or loans.

Women's restricted mobility and access to assets and resources make their links to everyday survival precarious and increase their vulnerability before, during, and after disasters (UN/ISDR 2001).

Although natural disasters vary in origin, in suddenness, and in predictability (with regional drought in Africa developing slowly, for example, in contrast to the rapid massing of a hurricane), disaster response commonly divides into shortand longer-term stages. Although each disaster is unique, response efforts tend to occur in phases: search and rescue, immediate relief (for immediate medical help, shelter, sanitation, and food), reconstruction and recovery, and long-term development. The immediate relief stage includes offering assistance to lessen human suffering and providing disasteraffected families with help and supplies to meet their basic daily needs. Relief activities typically include providing food, water, sanitation, temporary housing, psychological and social support, and basic health services in impermanent settings (for example, tent cities). This stage can last from three months to a year, depending on local conditions, and engage a range of international and local nongovernmental (NGOs) and governmental organizations.
Reconstruction and recovery are stages of postdisaster response following relief. Typical priorities in this period include relocation of affected communities to safer, sturdier temporary housing (for example, prefabricated settlements); large-scale repair and construction of permanent housing; restoration of running water, electricity, and sanitation; and establishment of community health and education facilities. Relief efforts also include restoring food supplies (and food security in rural areas) and commercial activities. This stage typically lasts two to three years, depending on the level of damage sus-

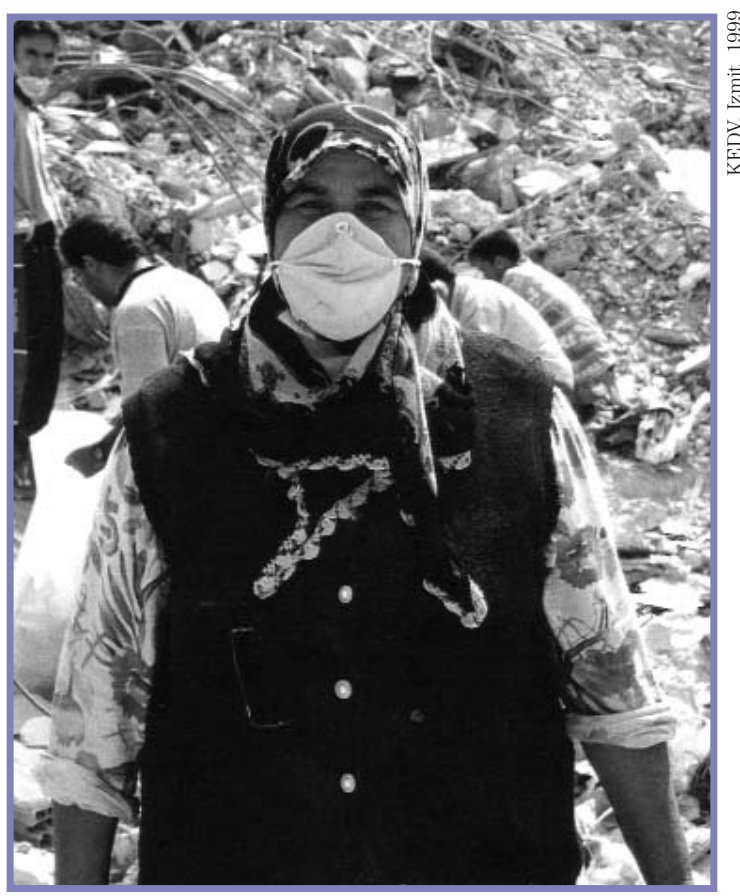


tained and access to resources, and it marks a period when affected families need clear information about entitlements and other opportunities associated with restoring their assets and livelihoods.

Community preparedness is the only practical solution for poor countries located in high-risk areas. The locals are the ones who can bring any effective help in the first few hours, and it is their capacity that has to be strengthened. This is less heroic than flying in after the event waving fistfuls of dollars, but it is cheaper and demonstrably effective (IFRC 2001).

Across these stages, serious problems arise over what, when, and how disaster aid is delivered. International agencies and national governments typically provide emergency assistance in a top-down manner that reduces affected people to victims and passive recipients of aid. In a period when community involvement and cooperation could be encouraged and survivors could regain a measure of self-reliance by participating in setting priorities and distributing supplies, information, and work during the relief stage, agencies behave as benefactors and do things for, not with, survivors. This behavior wastes funds and fosters dependency and cynicism within affected communities-problems that carry over to the recovery stage.

Emergency relief and aid processes particularly disadvantage women who must organize food provision, shelter, and child and family care according to chaotic aid-delivery systems and entitlement procedures that rarely take their work or opinions into account. Although women commonly organize themselves to distribute supplies, establish shelter, and pool labor and resources to create community support services to meet basic family needs in the emergency period, their efforts are often invisible or go unacknowledged. For instance, after Hurricane Mitch hit Central America, "most relief workers expressed surprise at the range of women's involvement, (but) some purposely excluded women from activities based on their assumptions about gender roles" (Delaney and Schrader 2000:16). Whether by neglect or intent "field accounts amply demonstrate how unwritten and unexamined policies and practices disadvantage women, excluding them from food distribution systems . . . limiting their access to paid relief work programs, or excluding women survivors from decision-making positions in relief programs" (Enarson 2004:13).

Poor women face a number of hurdles in applying and qualifying for aid, including limited literacy, limited access to information on how to apply and navigate the bureaucracy, and eligibility requirements that exclude them. More frequently than not, entitlement guidelines in the relief and rehabilitation stage favor men over women, giving priority to property owners, tenants of record, bank-account holders, and perceived heads of households. Where employment assistance concentrates on workers in the formal economy and business aid is awarded to formal enterprises, women's economic position is eroded further.

In the reconstruction period, entitlement programs focus on individuals and their loss of property. This approach favors owners in affected communities and geographical regions and excludes or harms nonowners (the poor, women, and ethnic and other minorities). It also assigns priority to bricks-and-mortar programs to build housing, infrastructure, and business and tourist facilities, neglecting the priorities of the poor, who rely on informal economic subsistence activities and collective pooling of resources to survive and cope with crisis.

Although it is well documented that women's economic losses during disaster can be extensive, conventional disaster response has not been adapted to take women's productive and reproductive activities into account or to reflect 
how important housing and informally held resources and assets are to women's security. As a consequence, postdisaster aid and investments generally undermine women's collective capacity to surmount day-to-day problems and erode their economic base. As Enarson (2004: 14-15 notes:

Women's work is heavily impacted by disasters, and their economic losses can be extensive. Domestic work increases enormously when support systems such as child care, schools, clinics, public transportation and family networks are disrupted or destroyed. Damaged living spaces are damaged working spaces for all women. For those whose income is based on homework, the loss of housing often means the loss of workspace, tools, equipment, inventory, supplies and markets. [In addition,] domestic violence appears to increase when men's sense of control is diminished in disasters.

What conventional rescue and recovery programs that focus on delivery of food and supplies, large-scale construction projects, and environmental engineering programs fail to recognize is that women's participation in decisionmaking in all these undertakings could go a long way to sustain community recovery once emergency measures are lifted.

\section{Reshaping Disaster Response To Establish Opportunities for Women and Communities}

Postdisaster response and recovery programs represent huge investments by development and humanitarian relief agencies. Since 1980, the World Bank alone has invested "about $\$ 35$ billion dollars in loan commitments for projects that included at least one disaster component" (World Bank 2004:1). As devastating as natural disasters are, they can become focusing events, leading to improved future development:

Disasters should also be seen as an opportunity to improve pre-existing conditions, including sex equity. Reconstruction, therefore, should not be thought of simply as a process of replacing what has been lost, but also as an opportunity to perform actions that make the most under-

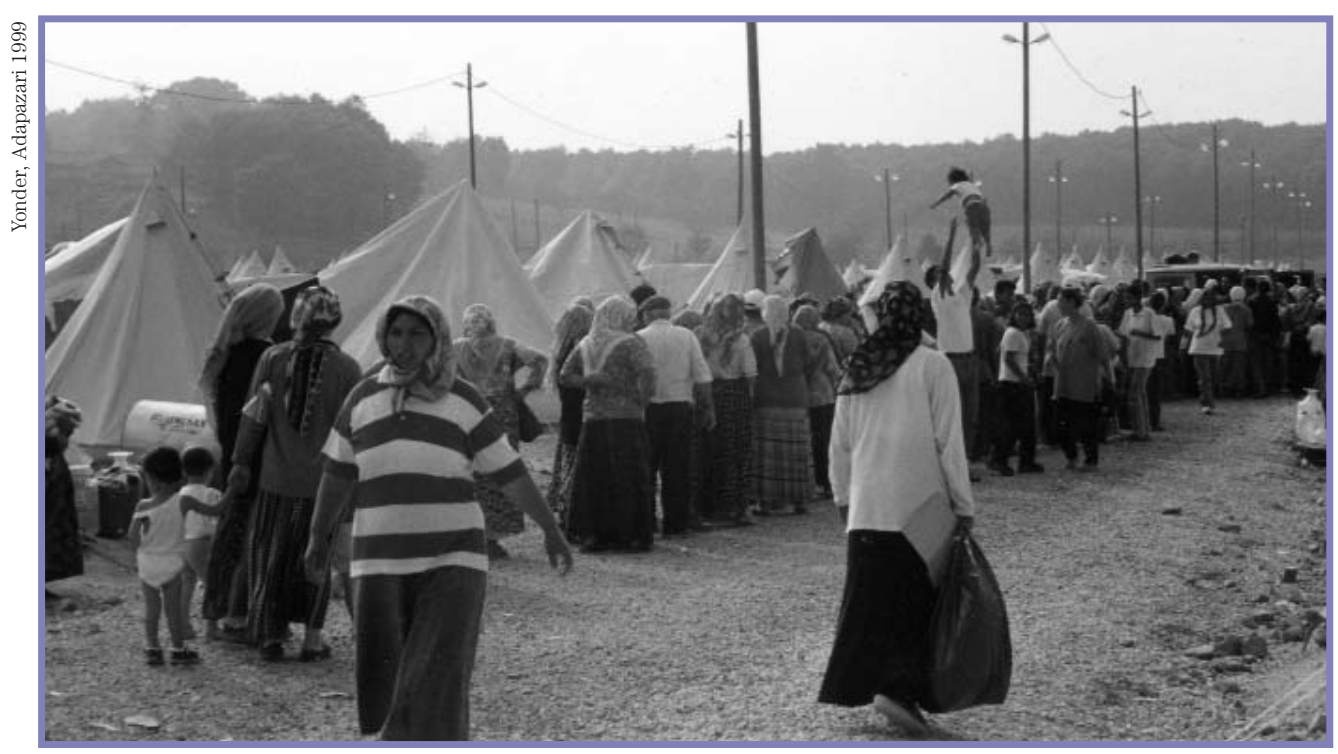




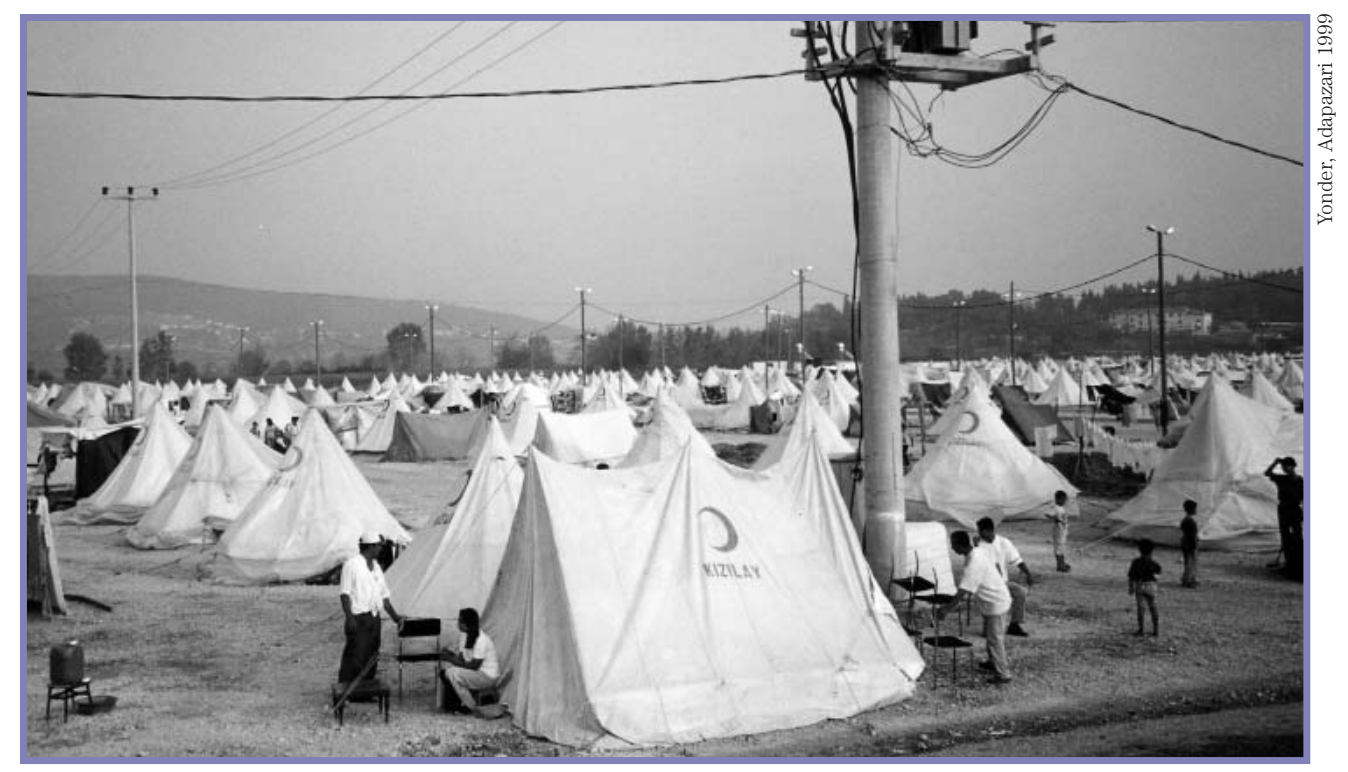

privileged groups less vulnerable, favor sex equity and improve living conditions for women, especially those who are heads of households. (UNECLAC 2003:45)

Postdisaster recovery can be seen as an opportunity to channel and leverage investments to upgrade the living standards of the poor, to enable the most marginalized to participate, and to establish dialogue mechanisms between affected citizens and government to foster accountability. It is a chance to "build back better" and apply principles of sustainable development and hazard reduction to communities and regions that are likely to remain at high risk of future disasters. To encourage such an approach, analyzing how the various stages of disaster response could be redesigned, is important.

During the relief phase, an infusion of funds and technical assistance often flows to the area, conventional rules and practices are questioned, and previously excluded groups - such as ethnic minorities and poor women-are informally involved and take on new roles. Disasters literally push women out of the confines of their homes and neighborhoods and lead them to take on nontraditional roles in the name of insuring their families' survival and well-being. For example, after Hurricane Mitch, women in Nicaragua and Honduras hauled cement and dug out wells; built temporary shelters, latrines, and temporary water-collection systems; and hauled away damaged fences, roof material, and agricultural implements (Delaney and Schrader 2000).

In many other recent postdisaster recovery situations, including those in India, Jamaica, and Mexico, women have been active in rebuilding their communities. Field reports confirm that women take the initiative in calling grassroots community meetings and organizing disaster-response coalitions (Enarson and Morrow 1998). They outnumber men in the leadership and membership of emergent grassroots groups working on disaster issues (Fothergill 1998; Enarson 2002). Analyses of the Mano community in Kobe, Japan, and of the Mulukutu community of Nicaragua, for example, have suggested that those communities with pre-existing strong organizations and/or women's groups were able to respond quickly, mobilize community resources efficiently, and reduce the amount of damage when disasters struck. 
Even in marginalized communities, natural disasters such as floods and hurricanes have inspired women living in extreme poverty to take action and organize their own self-help initiatives. For example, in Honduras, the Garifuna, an ethnic group of African descent watched their already poor communities be decimated when Hurricane Mitch swept the country in October 1998. Aid and relief programs did not reach their isolated North Atlantic coastal town and villages, and residents were forced to fend for themselves.

The Emergency Committee of Garifuna (Comite de Emergencía Garifuna) was formed right after the hurricane struck by a small group of community residents in Santa Rosa-eight women and four men. Deciding to work together and pool their limited resources, they started by going in boats to save those stranded in high waters and by sharing the food they had. The group quickly expanded and started working on a range of livelihood, community development, and governance initiatives. Women who had lost all their crops organized small cooperatives to pool their few resources and cultivate their land together. In remote areas, people who had lost nets and other fishing equipment began working in groups and giving part of their catch to the committee to distribute to those in need. Instead of approaching the authorities for aid to build houses one by one, 14 single mothers whose homes were destroyed banded together to set up new homes. Within a year, they were fighting opportunistic efforts to grab Garifuna land along the coast, including a proposed constitutional amendment that would have opened the coast to multinational corporations and large-scale tourist development.

Six years after the Mitch disaster, the Comite operates from an office in the settlements of Trujillo, but women still meet regularly in each other's homes or at the community center to discuss their work, and they travel to other Garifuna communities along the coast to support them in improving local conditions. Focused on food security, they organize fishing and the planting of banana and yucca, and they operate community seed and tool banks for collective support. To guard against future catastrophe, they have bought land to relocate some villages to higher ground and invited trainers from the Jamaican Women's Construction Collective who taught dozens of residents to identify and build hurricane-safe roofing in 2004. The same year, the United Nations Development Program's Equator Initiative Program selected this community-based organization as one of 26 best global practices in community involvement in managing natural resources and promoting sustainable livelihoods and environments.

Yet far more information is needed to bring about a shift in disaster response and investment toward poor communities and the women struggling to reorganize daily life in them. To date few, if any, in-depth case studies have documented long-term development-oriented disaster responses organized by women's groups over an extended period. Little is known about practical ways of supporting and sustaining women's participation for a three-to-six-year period in communities' emergency assistance, recovery, and hazard-reduction initiatives.

\section{Supporting Affected Women in Earthquake Recovery: Two Innovative NGOs in India and Turkey}

In the following sections, we present case studies from India and Turkey that address the gap in information and that provide a clear indication of what has already been done and how much more is possible. 
These case studies describe how groups of local women formed and organized to secure housing, livelihood activities, and basic services after earthquakes struck two states of India (Maharashtra and Gujarat) and the Marmara Region of Turkey. In both countries, women-focused, nongovernmental organizations from outside the devastated areas (Swayam Shikshan Prayog, or SSP, in India and Kadin Emegini Degerlendirme Vakfi, or KEDV, in Turkey) reached out to and organized local women's groups to enable women to participate in relief and recovery processes and to build the skills and capacities necessary to sustain their involvement. Because many NGOS offer direct services to communities rather than facilitate community participation, it is useful to examine the origins, shared approach, strategies, and working styles of the Indian and Turkish organizations involved. Such an examination illuminates ways in which NGOs can work differently to support and sustain women's involvement from postdisaster recovery to long-term development.

Swayam Shikshan Prayog (translated as "learning from one's own and others' experiences") in India and the Kadin Emegini Degerlendirme Vakfi (translated as "the foundation for the support of women's work") in Turkey, are two nonprofit organizations founded in the 1980s, each having more than 15 years' experience working with women and poor com- munities. Both organizations grew out of social movements in their countries and focused on helping women organize economic activities and participate in local development. Although SSP is primarily rural and KEDV is focused on urban areas, ${ }^{2}$ they share an approach to working with women that includes the following elements:

- They function as technical and financial resource partners to help local women's groups organize, plan, and implement long-term initiatives.

- They leverage funds, identify innovative grassroots practice, and teach methods that allow women's groups to participate in and lead community-to-community learning exchanges. Both groups believe women's effectiveness is strengthened by exposure to successful peer initiatives.

- They work with, and have the respect of local authorities, government officials, and other decisionmakers. And, in conjunction with women's groups, they both worked to sharpen decisionmakers' appreciation of women's contributions to relief and reconstruction programs. Most importantly, they persuade government officials to establish formal protocols and mandates that recognize and provide resources for women's involvement.

\footnotetext{
${ }^{2}$ SSP reflects the existence of a mature NGO sector in India that emerged along with the Indian government's antipoverty programs and efforts designed to assist poor women. Many of these organizations have their roots in the Ghandian movement that began during Indian Independence in the late 1940s and in a strong Indian women's movement. In the 1980s, international funding encouraged a proliferation of new types of autonomous, decentralized women's organizations that were critical of the social welfare approach and that focused on the empowerment of women at the local level. Most of these groups worked with mahila mandals (women's collectives in rural areas that were set up by the government and by NGOs). KEDV grew out of the 1980s feminist movement in Turkey, when, for the first time, several new groups emerged that were independent of political parties or labor unions. Some of these groups took up issues of political representation while others concentrated on the issue of violence in society, especially violence against women. The 1980s in Turkey was also a period of structural adjustment policies under a military regime, during which wage levels dropped, income polarization reached unprecedented levels, and more women entered the labor force under increasingly insecure and marginal conditions, without benefits or support services. KEDV was unique among the feminist groups in its choice to work with poor women in settlementbased centers on their social, economic, and community development concerns.
} 
- They are committed to networking and sharing their experiences with other community-based women's groups elsewhere that are involved in development and disaster-response initiatives as a means of improving their own programs and to pressing for program and policy change that will create opportunities for poor women nationally and globally.

Both organizations try to disseminate the lessons they have learned, informing policy design through advocacy and dialogue with major policymakers and funding agencies locally, nationally, and internationally.

The two organizations became acquainted in 1996 when they participated in the United Nations Habitat Conference in Istanbul. KEDV was chairing the NGO host committee and SSP was active in workshops on women's initiatives in human settlements. Both groups are also members of the GROOTS International network, ${ }^{3}$ so they came together again in 1999 when SSP hosted a GROOTS exchange in India, enabling KEDV leaders to see how the women's groups organized after the earthquake in Maharashtra. This exposure and information was invaluable when an earthquake struck Turkey later the same year, and it intensified bonds and direct collaboration between the two organizations.

Although SSP and KEDV used different strategies to help women participate in the postdisaster recovery processes, both groups saw disaster response as an opportunity for instituting positive change in long-term development of poor and working-class communities. They recognized that significant government and international resources were being allocated to the earthquake areas and that the crisis created new possibilities for collaboration among community groups, NGOs, and the government. They also saw major mistakes being made and resources wasted and knew that poor women would suffer the most if this waste continued. SSP and KEDV seized the opportunity to support women in organizing and participating in the reconstruction and development process. Together, their partnership with community women's groups offers a detailed overview of the potential for women's involvement in postdisaster recovery and reconstruction.

The case studies described below present women's experiences with earthquake recovery in chronological order, starting with the 1993 Maharashtra earthquake and women's work repairing and strengthening houses. A description of women's efforts to establish centers for women and children following the earthquake in the Marmara region of Turkey in 1999 follows. The examples conclude with an account of women in Gujarat, India, who became active following the 2000 earthquake there when SSP and the grassroots women's groups from Maharashtra traveled to this neighboring state to share experiences and pledge long-term assistance.

\footnotetext{
${ }^{3}$ Grassroots Organizations Operating Together in Sisterhood (GROOTS) International is a global network, established in 1989, by autonomous locally focused grassroots women's organizations and NGOs working in poor communities around the world. Members share an interest in increasing opportunities for peer learning among grassroots women's groups, promoting a new development knowledge base, generated from women's experiences and practices, and in engaging systems of public power to promote a shift in governance strategies to include low-income women. In the context of postdisaster response, GROOTS is linking groups who share a vision of engaging women in redevelopment and in processes that prevent future hazards from devastating the poor communities. It sponsored the majority of community learning exchanges described in this pamphlet, and with a sister coalition, the Huairou Commission, is working with multilateral institutions and innovative donors to change policy and programming to ensure that women participate in postdisaster response and mitigation initiatives. Specific elements of this advocacy are outlined in the conclusion. For more information, see http://www.groots.org or http://www.huairou.org.
} 


\section{Centering Women's Participation in Reconstruction Efforts in India: The SSP Experience in Maharashtra}

India is one of the most disaster-prone regions in the world. Floods, cyclones, droughts, and earthquakes hit South Asia every year, causing substantial human and material losses. About 57 percent of India, mostly in the northern Himalayan region and the Deccan plateau in the southern and central sections, is prone to earthquakes (Parasuraman and Unnikrishnan 2000).

In the past 12 years, two major earthquakes devastated communities in the west/central section of the country. On 30 September 1993, an earthquake with a magnitude of 6.3 on the seismic scale hit the Latur and Osmanabad districts in the Marathwada region of Maharashtra State. Fifteen hundred villages lay in the epicenter of the quake, and 69 of them were totally destroyed. Official figures placed the death toll near 8,000 and the number of those injured at 16,000. Material losses included more than 200,000 houses categorized as seriously damaged. Eight years later, another earthquake with a magnitude of 8.0 hit the Bhuj District in neighboring Gujarat State on 26 January 2001, disrupting lives in more than 620,000 households in cities and villages and resulting in the deaths of more than 20,000 people.

\section{The Maharashtran State Government's Recovery Programs in the Marathwada Region}

Nationally and at the state level, India had never faced a calamity as large as the 1993 Marathwada regional earthquake. The five-year rehabilitation program, launched by the Government of Maharashtra with
World Bank support, estimated to cost US\$216 million, was one of the largest in the country's history (Martin 2003). The government decided to relocate the villages hit hardest by the earthquake to new settlements and invited private and voluntary agencies to build the new houses and requisite infrastructure. For the 1,300 villages that were partially damaged, the government launched the Repair and Strengthening Program (R\&S) to rehabilitate as many damaged houses as possible. Accounting for the largest share of government aid, the R\&S program was designed as a homeownerdriven, self-help initiative that offered each affected family a grant of 17,000 rupees (approximately US\$425) toward the repair of their dwelling. Participating families were offered payments in stages if they provided family labor, additional materials and transport, and hired masons, and supervised the repair and strengthening of their houses.

From the outset, the program had problems. Access to information, technical support, and coordination were major obstacles. By giving subsidies for repair work to individual homeowners rather than to community groups, the program encouraged patronage, competition, and corruption. For example, politicians took control of identifying and listing which households were eligible for subsidies. Those homeowners who accepted the subsidy and began the repair process, found that masons were overcharging them or providing faulty construction. The appointment of more than a thousand government engineers to oversee and expedite reconstruction compounded the situation. Many engineers demanded bribes to provide homeowners with the certification they needed to qualify for additional payments, and the majority were unwilling to share information, train homeowners, or resolve problems.

Although "people-friendly" policies and community participation were in- 
tended to be innovative aspects of this program, neither the World Bank nor the government transferred decisionmaking power or resources in a manner that enabled village committees to form and function. Gender concerns also were missing from the reconstruction and community-participation strategies. Despite women's central role in the home and their related work, they were categorically ignored and socially excluded from planning, design, and repair processes associated with the recovery of their homes and local communities.

Meanwhile, tremors continued for a year after the quake, and many homeowners began to doubt that their traditional mud-roof and stone-wall houses could be made safe. Lacking information on construction technology and new design features, many believed that they needed new concrete houses and rejected the Repair and Strengthening Pro- gram. In village after village, people were frustrated and mistrustful of the complexities of the reconstruction process; the R\&S program was coming to a standstill, and the government's credibility was at stake.

In late 1994, the state government of Maharashtra appointed Swayam Shikshan Prayog (see Box 1) as its consultant to insure community participation in the Repair and Strengthening Program in 300 Latur and Osmanabad villages. This assignment required SSP to balance its role as an advisor to the state with its identity as an NGO committed to transferring decisionmaking power to local communities and especially to women. The time pressure to move villagers back into safe housing was great because it required SSP to find practical and innovative ways for the residents of 300 villages to learn, cooperate, and apply new technology and construction techniques rapidly.

\section{Box I \\ Swayam Shikshan Prayog (SSP): \\ A Maharashtran NGO Strengthening the Organizational Capacity of Rural Women and Their Role in Local Development}

Swayam Shikshan Prayog (SSP) was formally established as an NGO in 1988 to build the capacities of rural women's groups to access and manage development resources and to participate in decisionmaking processes affecting their families and communities. SSP's program experience was developed in the late $1980 \mathrm{~s}$ in a pilot collaborative effort with the government to enhance women's economic participation in an existing antipoverty program (DWCRA), funded by UNICEF (the United Nations Children's Fund) and the national and state governments. SSP facilitated a dialogue between community-based women's groups and local government officials in six districts in the Marathwada region of Maharasthra State. During this period, SSP piloted methods such as districtwide information fairs and community-to-community exchanges and dialogues for women designed to help them to learn to work with banks and government agencies.

Today SSP, with a staff of more than 60 , partners with women's collectives and communities across 889 villages, including 1,680 savings and credit groups that represent more than 22,000 female members. These women's groups address urgent issues such as credit, food security, water and sanitation, health, education, and social infrastructure by initiating demonstration projects, community planning, and skills training, and by increasing their participation in local governance. To support these efforts, $\mathrm{SSP}$, with headquarters in Bombay, operates field centers in the Maharashtran districts of Amaravati, Beed, Latur, Nanded, Osmanabad, Solapur, and the Gujarat districts of Jamnagar and Kutch. 


\section{Marathwadi Women's Involvement in Recovery and Reconstruction}

When the government appointed SSP to facilitate community participation, its staff_community organizers, engineers, and others-first looked at what had gone wrong or "gone missing." Through interviews, village mapping, and the use of rapid-appraisal techniques, they created a picture of the problems as well as the potential. The government authorities clearly lacked a common view of how to implement the program and what roles should be played by those involved (district officials, engineers, local governments, and affected residents). Village officials and homeowners lacked not only basic information but also opportunities to discuss and evaluate what was happening. In response to these problems, SSP undertook two concrete tasks: training government officials to disseminate information and facilitate bureaucratic processes (such as entitlement and procurement) and identifying community groups that could catalyze and engage local residents.

The latter task led SSP to decide to revive and reorient the governmentestablished women's groups (mahila mandals) as community agents for involving households in the Repair and Strengthening Program. By means of a large-scale publicity campaign (pamphlets and newspaper and radio advertisements), meetings were organized with 500 women's groups throughout the two affected districts. Large numbers of women gathered for these events. They evaluated the current program and discussed how women's groups could take the lead in creating visible community processes for participation. From this discussion, the idea emerged that women's groups would nominate members to make up a team to work as official village information and communication assistants (samvad sahayaks) within the R\&S program. To formalize these positions, SSP negotiated with the government so that the state, not SSP, would pay the samvad sahayaks to work in this capacity. In this way, the mahila mandals were recognized formally as the official interface between the communities and the government administration. Between April 1996 and March 1998, 300 samvad sahayaks were appointed in as many villages.

\section{Managing large-scale home repair programs}

In a mistrustful, deadline-driven, and initially hostile environment, the women's groups had to prove that they could inform, motivate, and supervise local homeowners. To prepare them for this assignment, SSP provided hands-on leadership training with more than 1,000 village women appointed by the mahila mandals. (Larger teams of women were created to support the 300 women officially named by the government.) Women were taught the basic construction techniques used for adapting and strengthening traditional village houses and learned how this type of construction would protect residents from future tremors. The information assistants and women's groups took their responsibilities to homeowners and community groups seriously and worked to ensure that people knew how to access and use their entitlements and understood and were able to supervise the use of earthquake-safe features in construction and make use of appropriate technology and local resources. They worked, as well, to involve women in planning and designing their houses and interacted with government agencies on behalf of their communities.

\footnotetext{
"Women were initially ridiculed.

'Oh, you have now become an engineer,' [they would say]."

—Suman, samvad sahayak in Usturi
} 
To accomplish these goals, the women's collectives organized themselves into teams to map and survey households in their villages. Visiting and interviewing neighboring homeowners, especially women, gave them a clear picture of situations in the villages and of the needs of their constituents. (See Box 2.)
As the women began to assume visible leadership positions, the women's groups faced dual and persistent challenges both to empower themselves and to build consensus among village residents and collaborating officials. For example, a number of women appointed as samvad sahayaks traveled to the first orientation

\section{Box 2}

\section{Women and Participatory Mapping: A First Step Toward Planning Settlements}

Participatory mapping is a useful and enjoyable exercise to bring women into a discussion of the concerns they have about their settlements and basic services. While drawing the map and discussing problems, women have a chance to take a focused look at their community. Mapping begins by drawing the most familiar elementsthe main road, houses, the school, the temple, and the shops. Some women become aware for the first time where their settlements are in relation to where the market is, where the water resources are, whether there are any vacant lots or houses, who lives where, and who obtained what from the government. It prompts them to talk about the condition of the community facilities, the power structure of the community, and how resources are allocated.

Once all the information has been collected and mapped, the next step is to discuss women's priorities and organize a plan of action. One benefit of the mapping exercise is to prepare women to read technical maps and plans. As valuable sources of data and visual support, the maps help women in their negotiations with government officials and technical staff.

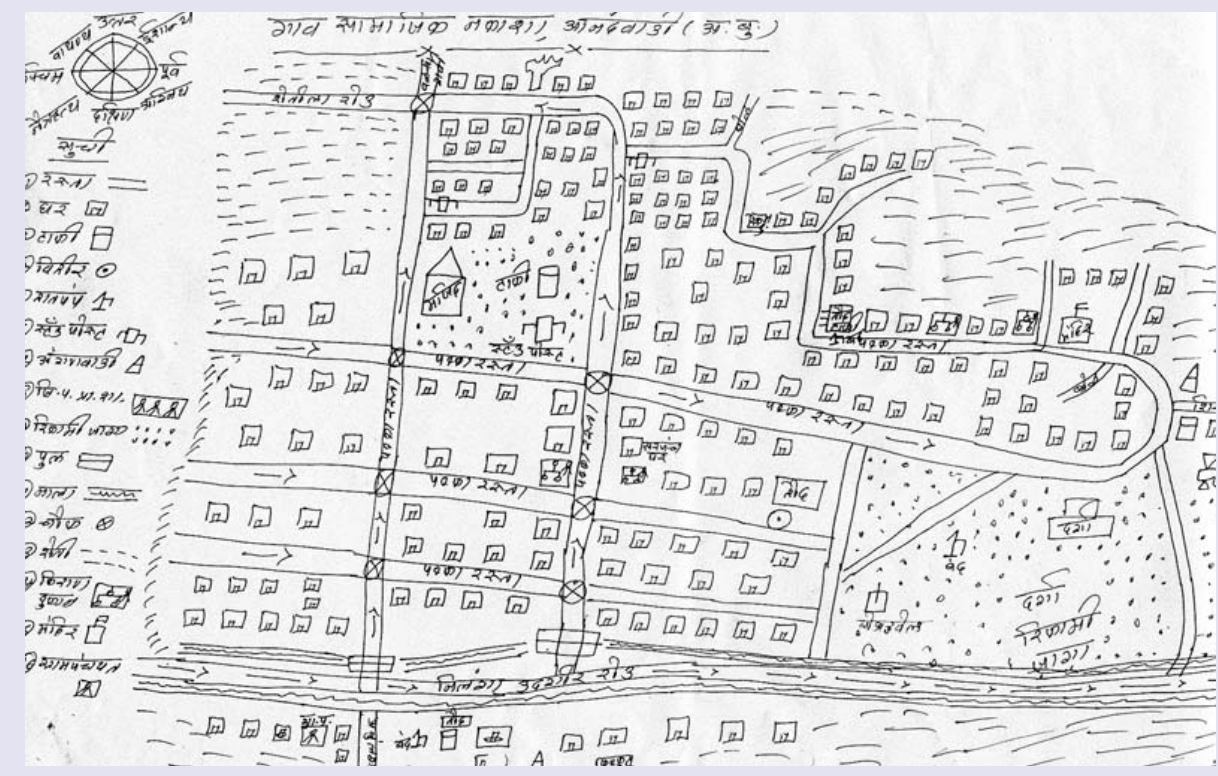


meeting accompanied by male members of their families, explaining that this made them feel more secure. Yet some men-family members and village leaders-hindered rather than helped women assume their new public roles, expressing shock that "the government could actually offer jobs to women." Engineers and bankers often withheld information from the leaders or simply turned them away, and masons commonly thwarted women's efforts to supervise their work.

These realities required SSP to make investments in a range of simple strategies to help women counter social hostility and promote public responsiveness to the urgency of repairing local houses. Women organized themselves to:

- work in a team, never alone;

- speak with everyone in the village, regardless of caste, age, or gender to publicly foster an open, inclusive, approach;

- support local village assemblies (gram sabhas) to function as informed, proactive, problem-solving bodies; and

- speak frankly and directly about problems (such as shortages, corruption, and lack of information).

The groups held informal meetings in village lanes to bring women (especially those from poor and lower-caste families) out of their homes to discuss their concerns about the R\&S process. They also used biweekly village council meetings and assemblies to share information about aid to homeowners and program progress and to register how water and transportation shortages and similar problems were blocking house repairs. When confronting hostility or corruption, teams of women would approach households or officials and speak directly, no matter how high up in the hierarchy the problem occurred. Women from Usturi, for example, went directly to top district officials to complain about a junior engineer who was taking bribes and to insist that his lower-level colleagues were fully supporting his behavior.

As women's intention to improve the situation became clear and officials were forced to act, resistance lessened, and cooperation grew. Even masons and engineers became open to adapting the design of houses to include features that women householders considered priorities, including, bathrooms, semi-open space between living room and bathroom, chimneys, strong shelves and containers for grain storage, and corners for religious offerings. Gradually, the repaired houses began to incorporate these practical elements as well as the traditional welcome symbols valued by the community. As villagers experienced being engaged as homeowners and partners (rather than as victims or beneficiaries of aid), trust and participation grew. They became more active, donating labor, buying materials with their own funds, and advancing payment to hire masons and laborers. The women's groups up-scaled these initiatives by promoting continuous cooperation among homeowners for purchasing and transporting materials in bulk and pooling their labor.

As this level of participation and partnership increased, Swayam Shikshan Prayog realized that additional staff and technical support were needed to help women multiply their gains and expand their involvement. With a team of engineers and expert masons, SSP established "leading villages" to demonstrate and implement the safest, most user-friendly construction methods. Mahila mandal members as well as local masons received training in earthquake-safe techniques and how to combine these with the design features that local women had requested. Within a village, the samvad sahayaks held regular meetings with 
homeowners, offering technical advice on how to choose and purchase building materials collectively, design a house, and implement new construction techniques.

These "leading villages" proved to be an effective means for connecting women's groups across communities as teams of leaders routinely journeyed back and forth to learn firsthand how to apply new building processes at home. Exposure to one village's success energized others. Soon, groups of homeowners began to build houses collectively, sharing costs and designs and jointly dealing with the engineers and supervision of masons and other laborers. As people found self-help solutions to the shortage of masons, water, and cash, their problem-solving skills improved. They began to recycle materials from their traditional houses-doors, window frames, stones, bamboo, and sheets of tin. In several villages, women's groups set up committees for accessing water, pur- chasing materials, supervising construction, and managing cash flow (including handling the documentation required to expedite government payments).

\section{Interacting with village, block, and district governments}

Prior to the earthquake, women were not regularly included in local council meetings (nor did these meetings take place regularly). To keep the repair process on track, however, women's groups organized community women to participate in village assemblies and prepared them to describe the problems of their households to local leaders (gram panchayat members) so that the leaders would be forced to respond with collective solutions and action. In several villages where local governments previously had not conducted village assemblies, women's groups pressured local leaders

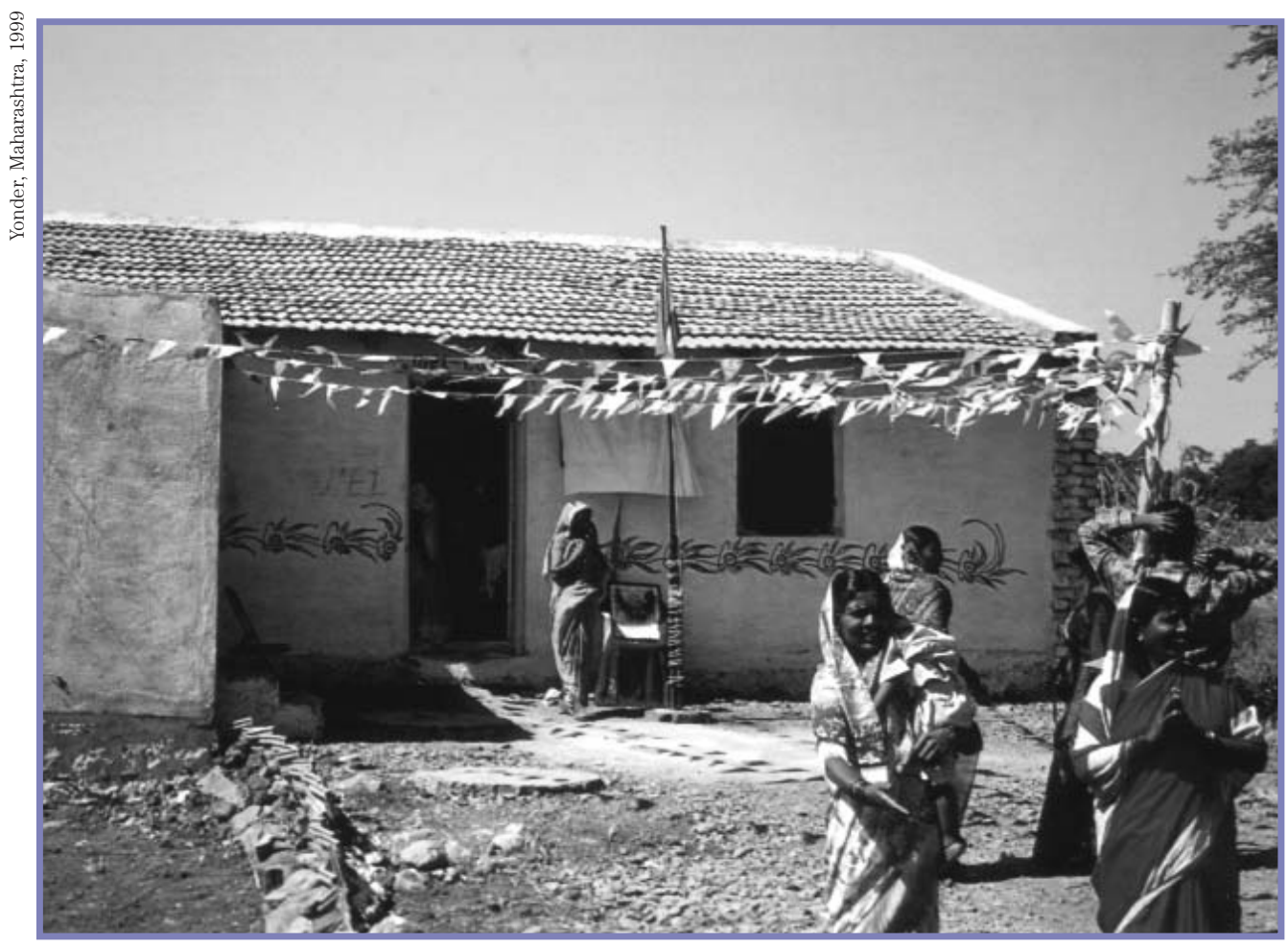


to do so. Women used these assemblies as public platforms for demanding changes in procedures and government accountability, and for pressuring influential local men, including bankers, to support them.

Early in the reconstruction process, women's groups had begun to meet with senior district government officials (the district is an administrative unit in charge of dozens of villages) to report formally on village problems and decisions. Over time, they persuaded block and district officials to attend village assemblies regularly in order to share information and make decisions together with affected families.

The dramatic increase in women's interaction with engineers and government officials and their participation in village assemblies and meetings produced many benefits. Women helped to expose and reduce local corruption and to promote greater public disclosure of information and investments. They set an example by publicly displaying progress charts, reviewing the goals and outcomes of meetings, and convening public dialogues between bureaucrats and affected homeowners. The collaborations women promoted also saved money, advanced public safety, and produced restored houses that included features that reduced women's domestic work and improved living conditions.

Since the women took the initiative to engage themselves, the government started understanding the problems better. This engagement and experience helped us gain confidence.

-Rukmini Koli, former samvad sahayah and former headwoman of Rajuri in Osmanabad

As local women gained a reputation as resource providers and problem-solvers, social relations also changed. Working together across caste lines became more acceptable, and traditional discrimination was reduced. Officials' became responsive and proactive in addressing problems and complaints, and they trusted women's information. Community support for women's greater participation, both within and outside of the family, helped strengthen women's political identity. Within two years, women stood for local panchayat elections, with the support of their groups, to advance the community development they had started.

\section{Building and managing public centers}

As the R\&S program wound down in Latur and Osmanabad districts, the local women's groups and SSP recognized the need to take practical steps to ensure that women stayed active in public life. In conversations between SSP and the groups, the women outlined their desire to secure independent public centers that they could manage and control. They envisioned these as permanent "public homes" that women's groups from five to nine nearby villages could share and operate as information, training, and resource centers. They knew that if they had their own space, they would not have to negotiate with men for access to public meeting spaces or confine their activities to their homes.

These newly evolved public women's information centers, known as mahila mahiti kendras (MMK), required group ingenuity to start and quickly multiplied across the two districts by the same learning-by-doing-and-seeing methods that SSP had fostered in the past. Box 3 summarizes some of the steps the group in Usturi took to build their MMK.

As women's demand for information centers grew, SSP arrived at a formula by which local women's groups were expected to identify and negotiate for the necessary land, provide the labor and 


\section{Box 3 \\ Usturi Village Women Construct Their Mahiti Kendra (Women's Communication Center)}

In Usturi village, the women's group began by surveying the vacant or unused available land in the area. They approached the vice-sarpanch (village headman) to ask if the local government could contribute land, only to be offered plots that were either too small, unsafe, or in marshy areas. Their survey had revealed a large, unused piece of land adjacent to a temple. The plot included an existing structure that could provide sufficient building materials for construction of their center.

The women contacted the owner, a religious figure living in Mumbai, and he agreed to donate his plot for the center if they would leave him a room to worship in whenever he visited the area. The women agreed and consulted SSP, people in the village, and the government land official to start the legal procedures for taking title to the plot. In a short time, they had signed the necessary papers.

To prepare for construction, the women negotiated agreements with neighboring families and the temple authority to share adjoining walls and to gain rights of access. Once the Usturi women had their title in hand, several of their leaders traveled to Pune to visit a site managed by a women's federation and learn how to make soil cement blocks and concrete beams. Eager to construct the building themselves, the Usturi women asked SSP for masonry training on their site. The training was organized to strengthen connections across the women's groups. In all, 80 group members from nine surrounding villages participated.

To build local support, the Usturi women invited local masons, carpenters, and blacksmiths to take part. The women explained to everyone that construction would be affordable only if many people helped out, creating space for men and women to participate. While some women gained construction skills, others helped by carrying materials, clearing the site or mixing mortar. Four women supervised the site in daily shifts, and the women's group developed a simple method for keeping a record of everyone's contribution (SSP Publications [2000a]). some of the materials, and raise funds locally. In turn, SSP would match a part of the funds collected for construction and provide training in construction techniques.

In the years since the Maharashtran earthquake rehabilitation program officially came to a close, the women's groups involved have sustained a high degree of activism in local development projects and in local governance. In Belwadi, where poor families were frequently keeping their children, particularly girls, out of school, the savings and credit groups began supporting an education campaign that provided girls with loans for bus fare, books, and school uniforms. By the end of the campaign, all of the girls in the village were attending school.

The women's group in Kajala village collaborates with local council members on community sanitation and other development projects. Throughout the narrow village, signs with slogans remind residents to keep the village clean. A common washing area has been established, as has a garden of medicinal herbs. Residents claim that cleaning up the village resulted in a significant reduction in the incidence of malaria. 


\section{Creating Spaces for Women in Relief, Recovery, and Reconstruction Efforts in Turkey: The Foundation for the Support of Women's Work (KEDV)}

\section{The Marmara Earthquake}

Turkey is at high risk for earthquakes, which account for the majority of damage to the country caused by natural disasters. A destructive earthquake occurs about every one and a half years; more than 90 percent of the country's total surface area is at seismic risk. In fact, more than half of Turkey's land area and population are first- and second-degree risk zones. ${ }^{4}$

Two earthquakes in the Marmara Region, occurring on 17 August and 12 November 1999, were the strongest ever experienced in Turkey, with fatality rates five times greater than those of previous quakes. Rated at 7.4 and 7.2 on the seismic scale, they occurred in the most densely urbanized and industrialized region of the country where 23 percent of the country's population and 47 percent of Turkey's gross national product were concentrated and affected. According to official figures, more than 18,000 people died in the two quakes and about 48,900 were injured. About 100,000 housing units were destroyed; more than 250,000 units received serious to moderate damage. Estimates of economic damage ranged from US $\$ 5$ to 6.5 billion.

Located adjacent to the Istanbul Metropolitan Area, the Marmara region had a thriving and diverse economy. Some cities like Izmit were highly industrialized; Adapazari and Duzce were wealthy agricultural provinces with flourishing trade. A major navy base was situated in
Golcuk; a middle-class summer resort was nearby. The majority of new migrants to the area had fled from civil strife and economic problems in the Kurdish region in Southeast Turkey. As a result, the earthquake disrupted the lives of people with highly diverse social, economic, and cultural backgrounds, resources, and needs.

\section{The Turkish Government's Response and Recovery Programs}

In the few hours that followed the first earthquake on August 17, volunteers and donations (food, clothing, household goods, medicine, and other necessities) started to flow into the area. As one observer put it, "As blood gushes to an open wound, volunteers flowed to the area. Anyone who could use a shovel or dress a wound, rushed to the area from all parts of the country" (Coskun 2001). Even if uncoordinated and inexperienced, volunteers and local people performed most of the immediate rescue work. Government and military forces and international rescue teams arrived 72 hours later. By that time, local people and volunteers had accounted for most of the 10,000 people that were pulled out of the rubble; professional teams rescued only about 500 more.

Despite a second earthquake that devastated the region within 86 days of the first one, the government-supported by an outpouring of international assistance from various governments and aid agencies - was able to rebuild the basic infrastructure and provide temporary accommodation for about 800,000 in 121 tent cities. Within four to nine months, about 42,000 prefabricated temporary housing units were completed; NGOs and the private sector contributed onefourth of the total number of units.

\footnotetext{
${ }^{4}$ The figures cited in this section are from the UN Habitat+5 draft report for Turkey (2000).
} 
Although the speed with which the prefabricated houses were constructed was admirable, the units were designed and built without input from local residents, women's groups, or NGOs, so that the size, quality, and location of the temporary housing proved controversial. No attention was paid to the livelihood needs of the poor, particularly to those of women, so that many families refused to leave their tents because leaving would cause them to lose their food aid and they would have to move far from their sources of income. Rent subsidies were offered to households that chose to find their own living quarters, but this offer led to rent inflation and evictions, thus driving more poor families to seek shelter in the temporary housing settlements.

Even though the majority of small businesses were destroyed and layoffs of workers continued to contribute to widespread unemployment in the area, the reconstruction program ignored people's livelihood needs and replacement infrastructure for many businesses (four years after the earthquake, the 14,500 destroyed businesses were offered only temporary accommodation). The government chose to focus on brick-and-mortar solutions and use recovery aid to construct large-scale permanent housing. Furthermore, the government's housing program targeted only homeowners, so at least as many households did not qualify for housing support from the government because they were tenants or had lived in dwellings without clear legal tenure.

Ultimately, a large proportion of this latter group were stranded in temporary housing settlements that were scheduled to be evacuated and shut down immediately after completion of government-sponsored housing projects. Because thousands of households, especially those of the poorest families, faced serious shelter problems as a result of soaring rents and unreliable repairs, some prefabricated housing settlements (more than 13,000 units) had to be maintained after almost all of the 40,000 new units were completed and allocated to homeowners by the end of 2003 .

The majority of the homeowners who applied for government assistance (96 percent) were qualified to receive it. Many families with alternative options (living with relatives, having savings, or owning a home in another province) took the government's housing subsidy and left the area, but the majority of displaced people stayed and sought shelter. First, they lived in tent cities and later in the temporary prefabricated housing settlements. Those whose houses were only moderately damaged received a lumpsum payment to use for repairs. Those whose housing was destroyed could choose either to receive credit for reconstruction or apply the credit toward new permanent housing built by the government. This policy meant different things to different people. For some homeowners, it was an opportunity to improve the quality of their housing; for others, it was a chance to recover some portion of their life savings. Yet this money was a loan that had to be paid back over time, and for some, especially for retired people, the government housing repayment plan was burdensome.

On 1 June 2000, the Ministry of Public Works and Housing began construction of 40,000 housing units financed by the World Bank and European Council Development Bank credits, by the Ministry, and by private donations. Again, the public did not have the opportunity to participate in decisions about the location, design, or construction of these settlements, nor about the terms of the repayment scheme. The Ministry conducted a small sample survey to determine the types of housing to be produced, and a few token public meetings were held in connection with the units to be built with World Bank credits, but 
these efforts were largely public relations strategies to gain support for predetermined plans. As in the case of the temporary shelters, site selection was controversial; many of the new settlements were to be located on prime agricultural land and far from city centers. A public outcry arose concerning the selection of developers for government-sponsored construction of permanent housing. Some of the developers awarded these lucrative contracts simultaneously were being sued for malpractice and for causing loss of life.

\section{Women Organize Relief in the Tent Cities}

The government's initial response after the Marmara earthquake was to house those displaced from their homes in tent cities. Poor women whose homes had been destroyed circulated, searching for ways to ensure the safety and survival of their families. They were looking for food, collecting usable items, talking to the press, and caring for their families and the injured. Men, in contrast, seemed to be in shock from having lost their jobs, their life savings, and their health, and were looking for work. Some wandered off to escape the responsibilities brought by the disaster. In tent cities, women attended community meetings and interacted frequently with settlement administrators and local government representatives to obtain information and access to aid. They tried to raise money for their families, by selling handicrafts or by preparing and selling food (illegally) from their tents.

Members of Kadin Emegini Degerlendirme Vakfi (KEDV) became involved in disaster-relief and recovery efforts at the time of the earthquake, working as volunteers. (See Box 4 for a brief description of KEDV's organization and activities.) First, the staff helped organize a group of young volunteers to provide emergency aid, collaborating with the union of local shipyard owners. They used land, sea, and airways to respond to requests for help coming from devastated towns. As they observed the conditions in the area at first hand, KEDV stopped distributing food and supplies within the first few weeks to concentrate on what it could do most effectivelyprovide safe and secure community spaces for women and children. The volunteers were quick to observe that women could play a key role as agents in the relief and recovery process, but to do so they would need a place to come together, share information, and offer mutual support. Life had to return to normal as quickly as possible so that people would not become disaster victims dependent on outside aid. People had to rebuild their own lives, even if they received support from outside sources. As SSP had learned, KEDV realized that the disaster, as devastating as it was, could be turned into an opportunity for development and social change.

The first step KEDV took was to meet with local women, NGOs, and government officials to determine the most appropriate sites for new centers for women and children in tent cities. KEDV sought to identify tent campsites that could accommodate the largest number of poor families, with cooperative camp administrators, and sites that appeared as if they could be sustained for the longest periods of time. The first centers were set up in Camlitepe, Cephanelik (Izmit province), Gözlementepe (Golcuk province), and Emirdag (Adapazari province). Because of KEDV's ongoing partnership with the Social Services and Child Protection Administration (Sosyal Hizmet ve Çocuk Esirgeme KurumuSHÇEK) and a protocol signed with its regional administration, the organization already had a high degree of legitimacy, an advantage that helped to quicken the bureaucratic procedures for obtaining access to space. 


\section{Box 4}

\section{Kadin Emegini Degerlendirme Vakfi (KEDV-The Foundation for the Support of Women's Work): Partnering To Establish Women and Children Centers that Women Control}

Kadin Emegini Degerlendirme Vakfi (KEDV) was established in 1986 by a small group of Istanbul-based professional women with grassroots backgrounds. Its mission was to support poor women so that they could organize to respond to basic needs and to develop the capacities to improve their own lives and communities. KEDV began by working with poor women from settlements around Istanbul who had expressed the need for community-based child-care services to keep their children safe while they worked. KEDV helped these women organize and negotiate with local municipalities for public space where parents could operate child-care centers with adjacent women's rooms that offer a range of capacity-building programs. In addition to providing an essential service to working women, the child-care centers also offered a socially legitimate reason for women to leave their homes to meet with their peers, thereby reducing their isolation.
KEDV's participatory approach, reliance on local resources, and success in developing strategic partnerships with both the private sector and government agencies was unique among the newly emerging NGOs in Turkey. It formed successful partnerships, including one with the Social Services and Child Protection Administration (SHÇEK), in order to gain access to resources and also to gain visibility and recognition for its work with poor women. The primarily source of KEDV's outside funding initially (and to the present) was the Bernard Van Leer Foundation in the Netherlands. With headquarters in Istanbul, KEDV now works as a resource partner with 17 centers for women and children and with 20 women's savings and credit groups in low-income neighborhoods of Istanbul, in earthquake-affected areas in the Marmara region, and in southeastern Turkey. It maintains a staff of 25 to 35 people, including women who work in the local centers.
Four new tents were bought to be used as women's centers, and SHÇEK provided additional tents for children's use, mobile toilets, and shipping containers that could be used for storage as well as for office and dormitory space for KEDV and SHÇEK staff. Several private companies donated storage containers that could be converted into rooms for groups of children as well as furnishings for these facilities. Thus, within two weeks, the first four centers for women and children had been set up in the makeshift world of tent cities.

Within days, local women appropriated the tents as a public living rooms and workspaces and organized their own activities. They cooked, received guests, made new friends, and held small sup- port-group sessions. Soon the tents were housing several income-earning schemes (described below). At the centers, the women discussed the earthquake, the relief programs, and events around the region. They organized exchange or marketing visits to Istanbul and started making plans for the future.

Generating income to support their families was a priority for most of the women. In late fall, KEDV was able to negotiate a contract with the Ministry of Tourism to produce toys at the centers. According to the protocol, 300 women produced 750 dolls each week; KEDV coordinated the production activities, and the ministry purchased and marketed the dolls. Over a five-month period, the 300 women who participated in the 


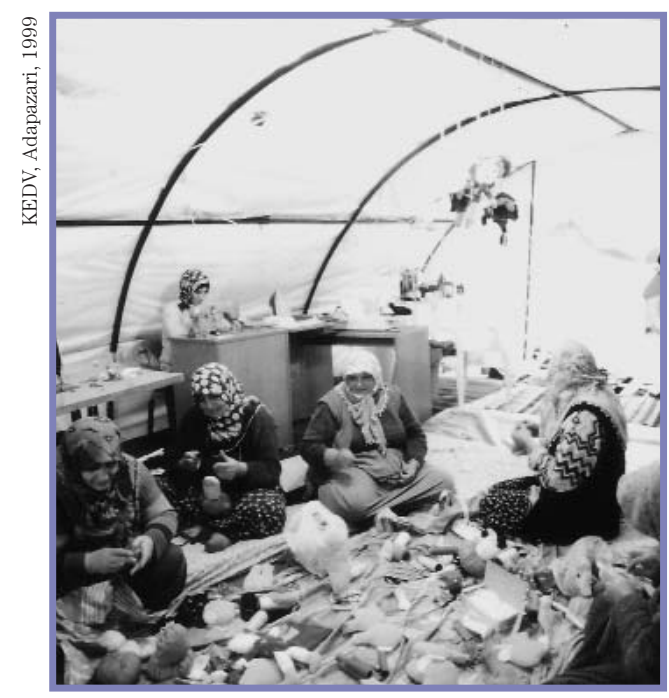

project produced more than 10,000 dolls and shared earnings of approximately US\$11,000. Beyond producing muchneeded income, this project introduced most of the women to the collective production process. At the same time, it served as a practical way for many of the women to overcome the trauma resulting from the disruption of their lives. As one woman remarked, "Every day, I had to get up, come to the tent, and be together with others. It helped me forget about my troubles." Others who did not participate in the doll project also came by to watch the work and chat. Ultimately, the collective process became a major attraction at the centers and provided women with an opportunity to get to know each other better and to plan future collective initiatives.

In less-damaged areas, people began to complete repairs on their homes and leave the tent cities. Some tent cities were closed down suddenly. For instance, a month after they opened, two of the centers (in Camlitepe and Gozlementepe) were ordered to move to another tent city. In areas like Camlitepe and Guney, many families decided to stay near their damaged homes to protect their property, even if they had to live in makeshift tents. Some women were concerned that these changes could cause them to lose access to their centers. They petitioned their municipalities to set up centers with support from the KEDV (see Box 5).

\section{We'll do anything to keep the center here. Children learn good values at child care and we have a place of our own. We can raise the money among ourselves. . . . This is public land; they should just give us space.} - A mother from Camlitepe tent city, September 1999

In the meantime, KEDV was able to secure funding from NOVIB (Oxfam, Netherlands) and the American Jewish World Service to set up eight centers for women and children in the temporary housing settlements under construction. Their construction required another round of meetings with officials and several site visits to identify settlements with the largest number of poor families, those who would stay in the area the longest, and, preferably, those who were located in close proximity to the existing centers. Because at this point the authorities were familiar with the work of KEDV, securing space was easier, and construction of the centers began in some of the largest settlements in the three provinces. ${ }^{5}$

\section{Creating Women and Children Centers in Temporary Housing Settlements}

The move from tent cities to prefabricated temporary settlements marked the

\footnotetext{
${ }^{5}$ In Kocaeli, the five settlements where the centers were built accommodated more than half (56 percent) of all residents in temporary housing in the province. In Adapazari, the two settlements accounted for more than a third, and the settlement in Duzce accounted for 18 percent of the population lodged in temporary housing. In all but one settlement, households paying rent made up the majority (60 to 80 percent) of residents.
} 


\section{Box 5}

\section{A Struggle for Control: The Guney Neighborhood Experience}

In Guney, KEDV joined the women in negotiations with the municipality for continuation of basic services (utilities and toilet facilities) on this site. The women calculated the budget and fees needed to hire a professional staff and divided the work among themselves. KEDV supported their efforts by organizing exchange visits to their center for women and children in Istanbul, and by training the women to manage the center and assist the only professional childcare worker employed at the site.

Soon, the Social Services Administration (SHÇEK) invited the women's group to move from the shipping containers they had been using into a new NGO-donated community building in the neighborhood. The women agreed on the condition that they would continue to be in charge of managing the child-care center and women's room with technical support from KEDV. Forty women attended the first meeting organized in the new building and decided on the rules for management of the new center. Within a few months, however, tensions began to develop between the women and SHÇEK staff. The building administrator, who believed that "ignorant women should leave child care to experts," tried to interfere in the management of the center and to limit the mothers' access to the building. Eventually, at the end of the summer, SHÇEK took over the community center, and the women's appeals to the governor's office and municipality for an alternate space was rejected with the explanation that sufficient child-care services existed already in the district.

Ultimately, even though the new center clearly demonstrated what women could accomplish when they combined their energy to reach a common goal, the fragility of their success in light of bureaucratic priorities illustrates the importance of institutionalizing women's gains and authority. transition from the relief to the recovery phase of the postdisaster intervention. Because humanitarian relief efforts were no longer needed, most of the local and international NGOs began to leave the earthquake area. The cooperative attitude that had existed between the public and nongovernmental organizations during the relief phase eroded. Only those NGOs with resources and a practical or longterm mission continued to work in the area during recovery and reconstruction.

The women who had moved into temporary prefabricated housing settlements in winter again found themselves isolated. This was at least the second time that many of these women had had to move after they lost their homes. Separated from their neighbors and friends in tent cities who had helped them, the women had to look for ways to improve their situation. Based on their previous experience at the centers, a few of these women took on formal roles as block representatives, but most were left to fend for themselves.

Living conditions in the overcrowded, hastily built prefabricated housing units were better than in the tent cities, but were still difficult. The settlements suffered from frequent infrastructure problems and lacked basic social services, and the barrack-style layout of buildings provided no informal gathering spaces for women. Along with widespread unemployment, social problems (including drinking and domestic violence) began to escalate. Tension grew, first, among homeowners who qualified for government housing credits and renters and unregistered tenants who did not, and second between residents and the settlement administrations (as a result of constant infrastructure problems, favoritism in the 


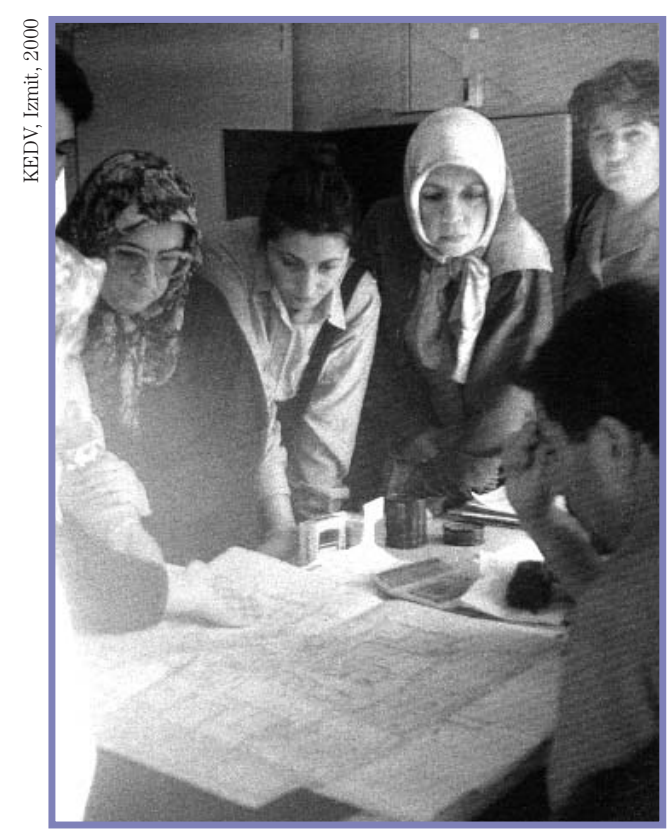

allocation of larger units, and the like). Because safe and affordable housing options were virtually unavailable elsewhere, residents who were not eligible for housing credits began to understand that living in these prefabricated dwellings might not be a temporary situation.

Within this context, the centers for women and children became the only source of community information and services in the settlements. As the initial shock of the disaster wore off under the hard living conditions of the temporary settlements, the women began to focus on their long-term economic and housing needs. Employment and income-generation became a critical concern. As the doll-making project ended, KEDV was able to involve some groups of women in the production of toys and educational materials, while other groups developed their own marketable products (such as household items and candles). The women organized teams to sell their products to local merchants, secured downtown stores from municipalities, and succeeded in obtaining stalls at two national chain department stores. Others explored different options. With funding and technical assistance from the Canadian International Development Agency (CIDA) and the Vancouver-based International Center for Sustainable Cities (ICSC), several women learned to make recycled paper, while others took up the nontraditional skill of carpentry. Two of the centers (Dernekkiri in Adapazari and Uzunçiftlik in Izmit) set up their own woodworking workshops where the women made not only wooden toys but also screens for windows and doors, which were in great demand in the settlements. They also explored ways to partner with local institutions to enhance their skills. For example, while they were discussing the difficulty of finding plumbers and electricians who would come to their settlements, women at some of the centers decided to organize workshops for training interested women as plumbers and electricians.

Another major concern that preoccupied women was earthquake-safe housing. A summer visit from SSP members from India helped women envision what they could accomplish. By late summer, with KEDV staff, they organized weekly community meetings on housing issues, attended by hundreds of women, and even a few men. At each center, a core group of determined women began to meet regularly to discuss strategy and take action. They selected two women as community-outreach workers to organize and facilitate meetings, take notes, disseminate information, and arrange for meetings with local authorities. The groups also began going door to door to collect information on the status of fellow residents in terms of their housing subsidies, livelihood concerns, and settlement-related problems. The women marked facilities and resources on settlement maps and noted other information they gathered (locations of vacant units, tenant households, house- 
holds with young children and/or disabled persons, and so forth). Collecting and owning this information, which the government did not have, provided the women with an asset they could use in negotiations with the government and made them feel empowered.

Three women from each center attended biweekly regional coordination meetings with KEDV staff to discuss their progress, findings, obstacles, strategies, and next steps, and where they identified local experts (lawyers, engineers, and developers) to invite to the centers to explain basic rules for safety in construction and issues related to eligibility for government programs. They strategized about the order in which to visit the local agencies and authorities and prepared questions to ask that they divided up among themselves so that everyone would have a chance to talk during the meeting. They organized group visits to local agencies and to the construction sites of the new permanent housing being built by the Ministry of Construction and Resettlement. At one center they discovered construction errors in some new permanent housing blocks in their district. This contributed to their concern that some of the new housing developers were the same ones who had built the buildings that collapsed during the earthquake, calling into question how the government was selecting contractors.

The women grew increasingly frustrated because on the one hand, they attended World Bank meetings where they received fragmented information and on the other hand, no public agency was prepared to take responsibility for establishing safe building and repair standards. Over time, the women began developing their own sense of credibility and standards for evaluating the government's accountability. They warned their peers from other centers to be vigilant and to keep good records. Meanwhile, because the government program did not address their housing needs, groups of tenant women began exploring and developing their own housing cooperatives linked to savings groups.

After the first few meetings, we realized that the local authorities did not have clear information about the government programs, either. They would just repeat what they and we already knew or would say things to make things look rosy. So we started taking notes in the meetings and asked them to confirm and sign the notes. Now they think twice before making empty promises.

—Nehir from Uzunciftlik, November 2000

As women experienced the benefits of acting together as a group, the centers reached out to collaborate more with each other. Women from different centers began to go to meetings with local authorities together. They exchanged the names and numbers of experts and officials who were helpful, and groups farther along in the process began to help the others, participating in their weekly meetings, and sharing information, experiences, and strategies. At the same time, attitudes were beginning to change within local households. As a woman from Yesilova remarked, "My husband used to complain that I spent too much time at the center. Now he is used to it and asks why I am home, even during the weekends."

Group discussions of shared concerns encouraged the women to push so that their priorities related to housing, social services, and livelihoods would appear on the local agenda. Recognizing that this would be a long-term process, the importance of staying together and sustaining their centers became clear. They began to the take the necessary steps to establish a formal identity as autonomous women's groups so that they could continue their negotiations with authori- 
ties and access resources on their own. With support from legal experts and friends, the women explored different organizational formats and decided on cooperatives as the most suitable structure for their needs and purposes. Meanwhile, a six-year protocol signed between KEDV and the Social Services and Child Protection Administration in 2001 provided more favorable conditions for sustaining the centers. ${ }^{6}$ By early 2003, six of the eight centers for women and children were consolidated as autonomous service-production cooperatives.

Also by 2003, four housing cooperatives were established by about 200 women from the three provinces, who began looking for funding and negotiating with the authorities for allocation of land for their cooperatives. This effort has required vigilance. For example, during their visits to public agencies, the women learned that the Ministry of Public Works and Housing was considering auctioning off land in temporary housing settlements to cooperatives that had been set up by tenant groups for building apartments. Even though site selection would be based on each settlement's tenure composition, the women had already gathered this information and could supply it to the Ministry. One outcome of this process was a promise from the Regional Coordinator of the Ministry of Public Works to give the women's cooperatives priority in land allocation.

\section{What the Women Accomplished}

Since the earthquake in September 1999, more than 10,000 women have been involved in the activities of the centers for women and children. While many local and international agencies were having a hard time finding local groups to take over the management of the service centers they had built, the grassroots women's groups organized around the centers took control of their situation. They formed savings and credit groups and initiated partnerships with local agencies to ensure the financial sustainability of their centers. Tenants organized around housing cooperatives to find a solution to their housing needs. Moreover, small groups of leaders participated in regional and international peer exchanges in Bulgaria, India, and Southeast Turkey, and most recently in Bam, Iran. These meetings gave them confidence to act as grassroots experts on microcredit schemes, housing processes, information gathering, and on the establishment and operation of centers for women and children.

\section{Transferring Skills and Experience: Marathwadi Women's Groups Support Earthquake- Struck Gujarati Women in Taking Action}

Women's groups that participate in emergency relief, resettlement, and reconstruction efforts following a natural disaster acquire significant knowledge and expertise that can greatly benefit communities that subsequently experience similar crises. When mechanisms are established for promoting the transfer of this knowledge from community to community, poor women are enabled to come out of their homes and form groups to assess their situation, organize, and participate in the range of decisions and programs that will

\footnotetext{
${ }^{6}$ The protocol allowed grassroots women's groups, beyond the emergency conditions of the disaster region, to set up and govern their own community child-care centers without having to hire an expert administrator. Therefore, this protocol was also an important step toward mainstreaming the establishment of community-run child-care centers throughout Turkey that would be monitored and assessed by KEDV and SHÇEK to develop proposals for legislation to disseminate the model.
} 
shape their immediate and long-term futures. When disasters strike, the opportunities to decrease women's marginalization arise early on, when norms of social control and male-dominated family structures are temporarily disrupted and weakened by the chaos that ensues. If affected women can meet and benefit from the experiences of other women who have managed to deal successfully with disaster-related issues, much valuable time can be saved and mistakes avoided. The aftermath of the earthquake in Gujarat in 2001 is one example where local women benefited from the help of their peers from Maharashtra and from the experiences of the Turkish women from the Marmara region.

A powerful earthquake, with an epicenter near Bhuj, struck the Indian state of Gujarat in late January 2001, and nearly a million families were left homeless. The Kutch region, a large part of which lies in the highest seismic hazard zone in India, was the hardest hitaccounting for 90 percent of all deaths and almost an equal share of all destroyed assets. The Kutch region had "high levels of social and economic vul- nerability and fragility even in 'normal' times" (Martin 2003:14)

With higher poverty and lower social indicators than in the rest of Gujarat, people's capacity to absorb and recover from the losses caused by hazard events is limited. The main sources of livelihood, agriculture, salt mining, handicrafts and trade have been seriously affected by the compound effects of earthquake and drought. . . . For a community trying to cope with a drought since 1999, the earthquake ... tested their resilience. While losing their habitat, employment and family support, poor rural women also lost the childcare, community, education, and health infrastructure. Many anganwadi centers (for women and child welfare) providing government assistance completely collapsed, leaving an estimated 1.5 million women and children without nutrition support and health services, as a UN team noted. (Martin 2003:30)

A tardy government response required survivors to mobilize relief and recovery efforts on their own, and a number of Gujarati women quickly sprang

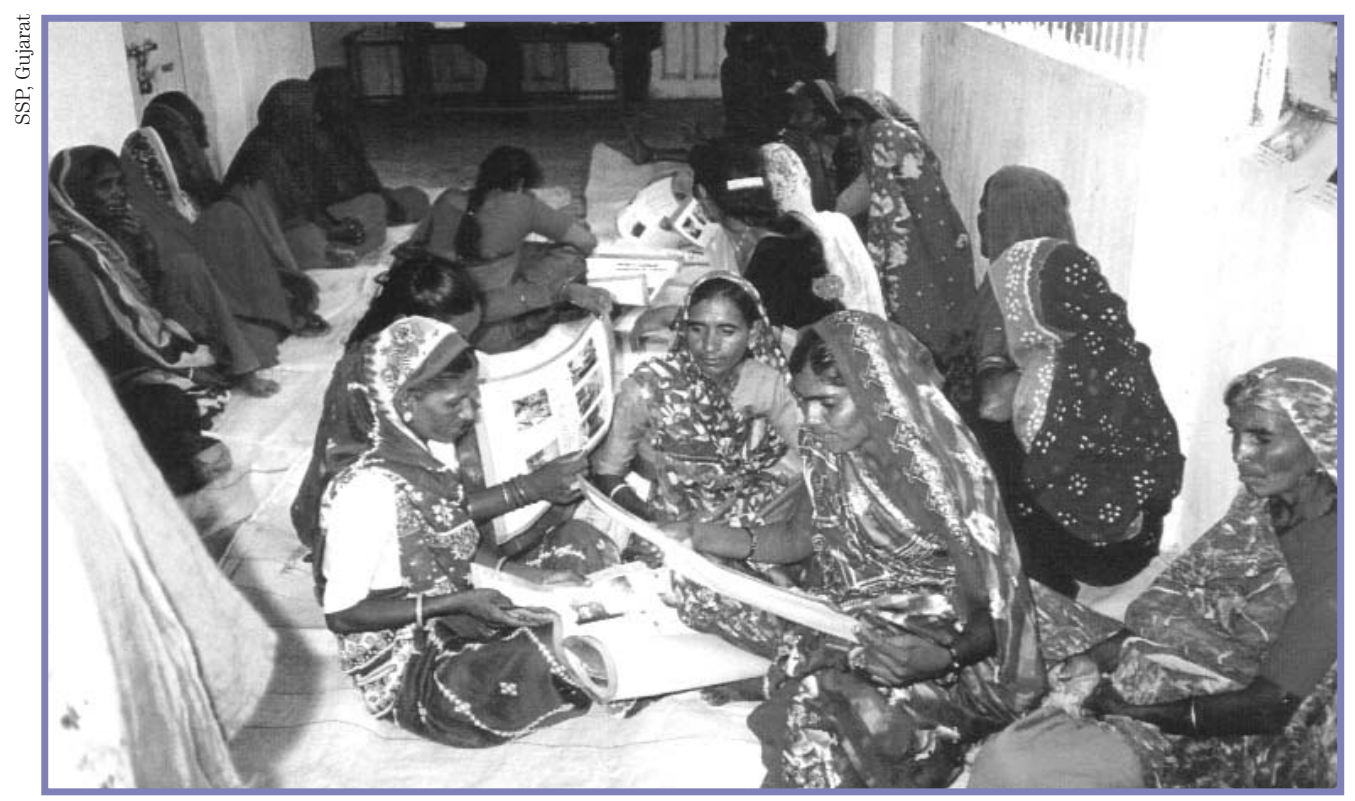




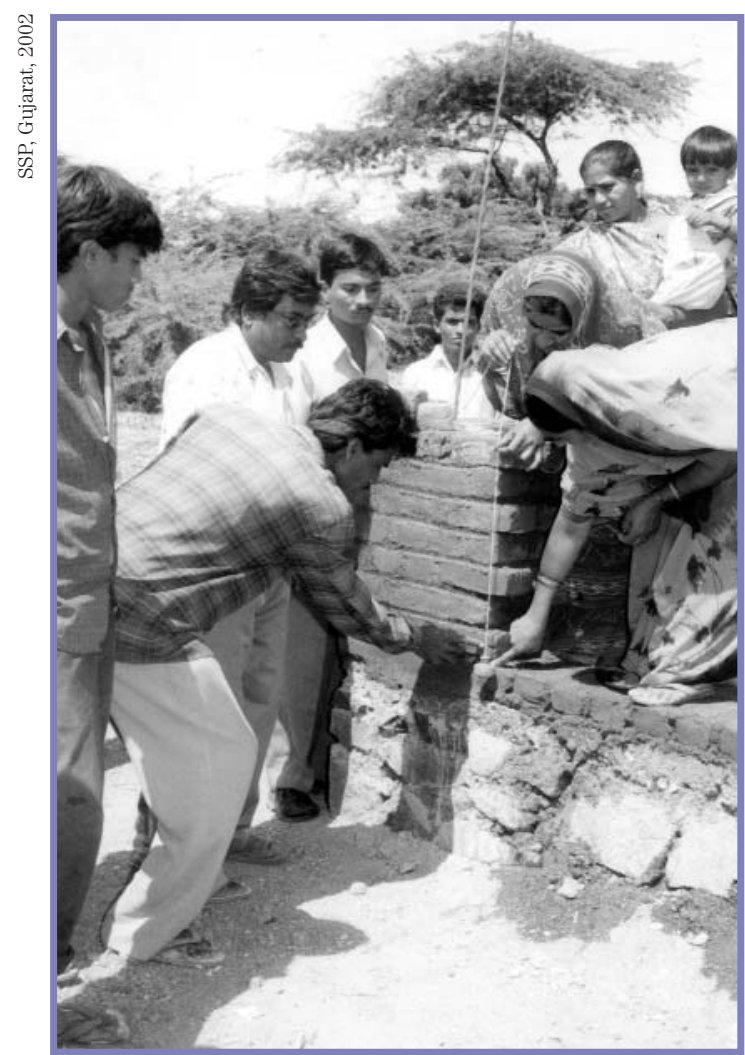

into action, summoning doctors, pulling children from the debris, and rescuing animals. Nevertheless, their initiatives were largely invisible.

Swayam Shikshan Prayog, collaborating with the Society for the Promotion of Area Resource Centers (SPARC), offered solidarity by soliciting corporate, international, and relief agency monies to help affected communities organize themselves. Pushed by the women's collectives in Maharashtra, SSP traveled with experienced leaders from these groups and with their own team of engineers and architects across the villages of Gujarat to determine how their postdisaster experience could be useful. Within several months, they were providing support to community initiatives in more than 200
Gujarati villages in Jamnagar, Kutch, and Rajkot districts in collaboration with several NGOS and districts' administration. ${ }^{7}$

SSP began its work by supporting community-to-community exchanges between women's group leaders from Latur and Osmanabad savings and credit federations (in Maharashtra) and affected women in three Gujarati districts. Focused on identifying and addressing the urgent practical needs of survivors, the exchanges enabled these experienced leaders to help their neighbors analyze their own situation and decide upon effective actions that could be taken. For example, they helped Gujarati women map the degree of damage the earthquake caused by asking: "What losses did you suffer after the quake? Was your house destroyed? How do you get food? Has family employment continued or been disrupted? Do you have money set aside or are you borrowing? How have your children's health and education been affected?"

Maharashtran women also shared stories of how they had coped and organized themselves to improve their living and working conditions. This sharing gave Gujarati women, more confined by caste and religious barriers than their visiting sisters, a vision of how they could justify participating in community recovery and work together across social differences.

In a short time, the government, armed with more than 300 million dollars from the Asian Development and World Banks, moved in to repair and strengthen more than 700,000 houses, construct dwellings for the homeless, and rebuild core infrastructure (schools, village health clinics, roads, and power grids). Stalled entitlement applications, bribe taking, and faulty repair and reconstruction processes repeated themselves in earthquake-devasta-

\footnotetext{
${ }^{7}$ SSP partnered with local and outside NGOs, including Anandi, Hum, and Oxfam India, to build women's capacities and create livelihood activities.
} 
ted villages across Gujarat, replaying the Maharashtran experience. When seasoned grassroots leaders visited their struggling peers, they urged the women to determine who was taking bribes, where bottlenecks existed in accessing entitlements and repair materials, and to decide how they would confront these problems collectively and sustain their action. For example Sultana (of Osmanabad) asked Dilharba of Jodia village:

Is it true that the engineer in Bhimkatta village asks for bribes to approve houses for the second installment of funds?

Dilharba: Yes, the engineer asks for bribes. I have been telling people that if your homes are using the proper earthquake safety guidelines, then you should not give the engineer any money. I completely discourage them from giving bribes to anyone.

Have you complained to anyone about the engineer who's asking for money?

Dilharba: No, we have not told anyone yet.

Why not? You should bring this to the attention of the Taluka District Office so that the corruption stops.

One year after the earthquake, women leaders from the Marathwadi (India) and Marmara (Turkey) regions, coordinated by SSP, met with Gujarati women to help them evaluate whether the recovery program was meeting their needs. At a public meeting with local officials (see photo), they listened as Gujarat women described how the scarcity of water and other development challenges in this drought-prone, conservative region, were interfering with the repair and reconstruction process. One woman reported:

In my village, we have received the first installment of funds to start the construction of houses. But if you don't get water for construction, how can you build your house? We get water in our village for one hour every three weeks. How can anyone construct houses in such a situation?

Gauriben of Jamnagar district described how her daughter spends most of the day standing in a long line waiting for water because of the shortages and demanded to know: "Why do I have to make a choice between making my daughter stand in a line for water or sending her to school?" A third woman, Sheetal, described how her group organized to compel officials to respond to their water shortage:

The women from Latur encouraged us to go and talk with the officials and request that the lead person come to our village to see conditions for himself. [We did, and] at first he got angry and refused to listen. We told him we could have him suspended if he didn't listen. So he calmed down and agreed to visit. Once he was there, he saw how severe the problem was, and he organized a meeting with the entire village where we decided to build a water tank. Since his visit, we've been getting a water tanker here everyday, [and will continue to] until our tank is built! (SSP Publications 2002)

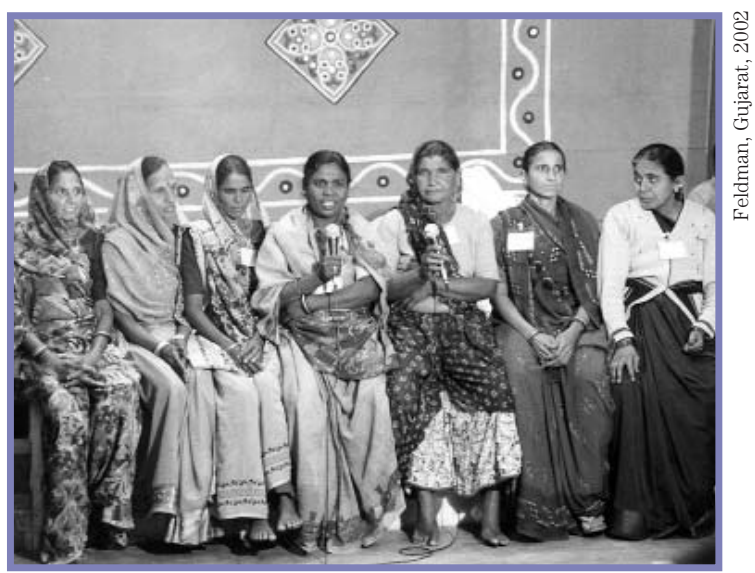




\section{Adapting Empowerment Strategies to Cultural and Social Conditions}

Despite their widespread poverty, the Gujarat villages where SSP worked had no active savings and credit groups. Initially, the Gujarati women resisted the idea of forming such groups, claiming they were uneducated and would not know how to operate as a group or handle money; some anticipated that men would forbid them to participate. However, after repeated visits, meetings, and study tours to observe the savings and credit groups in Latur and Osmanabad (where more than 15,000 women were running more than 1,100 groups), the Gujarati women agreed that they could start the process of saving and lending together (see Box 6).
For every step the Gujarati women took out of their homes, their appreciation grew for how the Maharashtran women had created tools to make their groups a permanent part of public life and development processes in their villages. From their numerous exchange visits, they soon became curious about the "whys" and "hows" of buildingfrom repairing and strengthening their homes to constructing the mahila mahiti kendras. Indeed, SSP helped train Gujarat women in construction methods once households were able to gain access to their payments and the repair and strengthening of houses were underway. Although women's restricted mobility shaped the ways in which they participated, nevertheless, Gujarati women used the information and training they had received to become involved. Accor-

\section{Box 6}

\section{Learning about Savings and Credit}

In early October 2001, a study tour was organized by ANANDI, a women's NGO, to help women from the quake-affected area learn about savings and credit groups. A group of 25 women from the villages of Jodia block, accompanied by a leader from Latur, visited Rakodia, a remote village in Maliya block lacking proper roads, electricity, and water. While there, they heard Khaleedaben, the leader of the host savings and credit group, describe the Rakodia group and the benefits it was yielding:

Not only do we save money by circulating low-interest loans but also we have started making and selling cement tanks with the money that we have saved. The profits from the sales go back to our savings group. So it gives us both an income and great empowerment.

As they met with the women and heard how they had organized themselves and learned to keep records and establish rules for governing the group, Bhanuben, a visitor from Utbeth Champer, began to see the potential.

Even though SSP has had meetings with us on the importance of forming savings groups, I did not really understand the concept clearly. I also thought it would be impossible to mobilize the women of my village to do this. But after coming here today and seeing what women in Rakodia have achieved, I can see the importance of women coming together. If Khaleedaban and the women here can do it, there is no reason why we can't make such progress in my village.

By the end of the visit all the women on the study tour were asking SSP if their colleagues from Latur and Osmanabad could come and help them form groups in their villages (SSP Publications 2002:10). 
ding to Phuliben of Jodhpur Vandh, in Rapar Kutch,

Today we are able to provide proper guidance to the masons when our homes are being built. . . . I also help to guide others in my community. If my home is being built right now, I go and ask other women whose homes will be built later to come and help me. Then when their homes are being built, I go and help them. In this way, many women have been coming together to work on rebuilding homes.

Numerous village women worked in construction: sifting sand, mixing cement, ensuring the right proportions of sand and cement, and supervising the masons to make sure that they were incorporating earthquake-safe features in the construction.

To establish mahiti kendras, women organized the work into five committees. Leaders in Khirsara village described these committees at a meeting with Jamnagar residents. They organized:

- a water committee responsible for ensuring that water is available for construction-arranging both access and transport to sites;

- a purchasing committee responsible for checking the prices and quality of construction materials before buying them;

- a materials committee responsible for keeping records of the materials coming in and the amount used, and for informing the purchasing committee when more materials are needed;

- an accounts committee responsible for recording the amounts spent daily on construction, literally tracking every expense from the day the foundation is excavated to the day the walls are painted;

- and a supervisory committee responsible for the overseeing construction, which records when the masons start and end work and all other daily construction activities and ensures that masons use appropriate, earthquakesafe building techniques.

Participating women have been eloquent in expressing how these processes have helped them learn to plan, solve problems, and negotiate and monitor planning and construction. A mahila mahiti kendra in a village, be it in Maharashtra or in Gujarat, symbolizes an important milestone in the learning process of local women. These multipurpose centers house the activities of women's groups from as many as 15 surrounding villages and testify to the ability of women working collectively to acquire land; to mobilize labor, materials, and monies; and to build and manage new community structures. Moreover, when women's groups can establish their own building, with their name on it, they acquire new status in their village.

\section{Conclusion}

\section{Claiming Opportunities With Innovative Strategies}

The case studies of the SSP and KEDV experience highlight how postdisaster situations can be opportunities to empower women at the grassroots level, build more resilient communities, and initiate long-term social change and development. They also illustrate how NGOs can focus on facilitating and partnering to leverage resources and thereby galvanize affected women's groups to scale up and sustain their energy and organization over the cycle of relief to reconstruction. Although the Indian and Turkish strategies were different, they jointly suggest key elements of effective practice.

In India, SSP began by negotiating with the government to secure the appointment of women as communication inter- 
mediaries, placing them at the center of reconstruction processes. The women's groups underwent training to take on this role: to motivate householders, build technical capacity, demonstrate collective arrangements, provide feedback, and monitor reconstruction. Over time, women acquired the confidence and skills to become community-development intermediaries, monitoring basic services, voicing women's priorities in their communities, initiating local development projects, and facilitating dialogues between their communities and government officials. Training of public agency staff concerning community and women's participation was also critical in ensuring the success of this process. As a result, 250,000 households were involved in earthquake-safe construction in Gujarat and Latur. As 4,000 women and families took loans; 1,200 women started businesses, and livelihoods and assets were stabilized. Communities organized for long-term development. Today, more than 800 women's groups work on health, education, water, and sanitation in their communities.

In Turkey, KEDV used a different entry point for women's participation. It began by creating public spaces for women and their children as a way to legitimize and sustain women's participation in the public sphere and to rebuild disrupted community networks. The centers for women and children provided women's groups with a place to meet, organize, learn new skills to start individual and collective businesses, and gather and share information on the reconstruction process. The centers also gave women's groups legitimacy in their dialogue and negotiations with officials for information, partnership contracts, and resources. Since the beginning of the relief phase, more than 10,000 women and their children have participated in various activities at the centers. Women's groups, organized as indepen- dent service and production cooperatives, also assumed control of six of the centers for women and children and started numerous savings and credits groups as well as collective and individual businesses. More than 100 women organized around tenant housing cooperatives and began negotiations with government agencies to seek a solution to their housing problems.

Both SSP and KEDV used peer learning exchanges among local women's groups as a capacity-building strategy. This approach promoted the rapid expansion of effective practice and demonstrated that women can function at the grassroots level as technical assistants to one another. An unexpected outcome is the eagerness and effectiveness of women's groups to provide support and guidance to other women's groups in areas experiencing disasters. One example is the Maharashtran women leaders who helped Gujarati women become information gatherers, challenge corrupt officials, scale up savings and credit groups, and establish public spaces to sustain their involvement in reconstruction. More recently, Turkish community women leaders from the Marmara area traveled to Bam, Iran to teach women who also survived a devastating earthquake how they had established centers for women and children in Turkey, negotiated with local authorities, and organized effective microfinance and enterprise projects (see photo).

\section{Lessons Learned}

Not only do the case studies pinpoint postdisaster opportunities for women's participation and contributions, they also underscore the conventional attitudinal and operational approaches to postdisaster programming and resource allocation that must be overcome to support women's grassroots organizations so that they can be fully effective in re- 


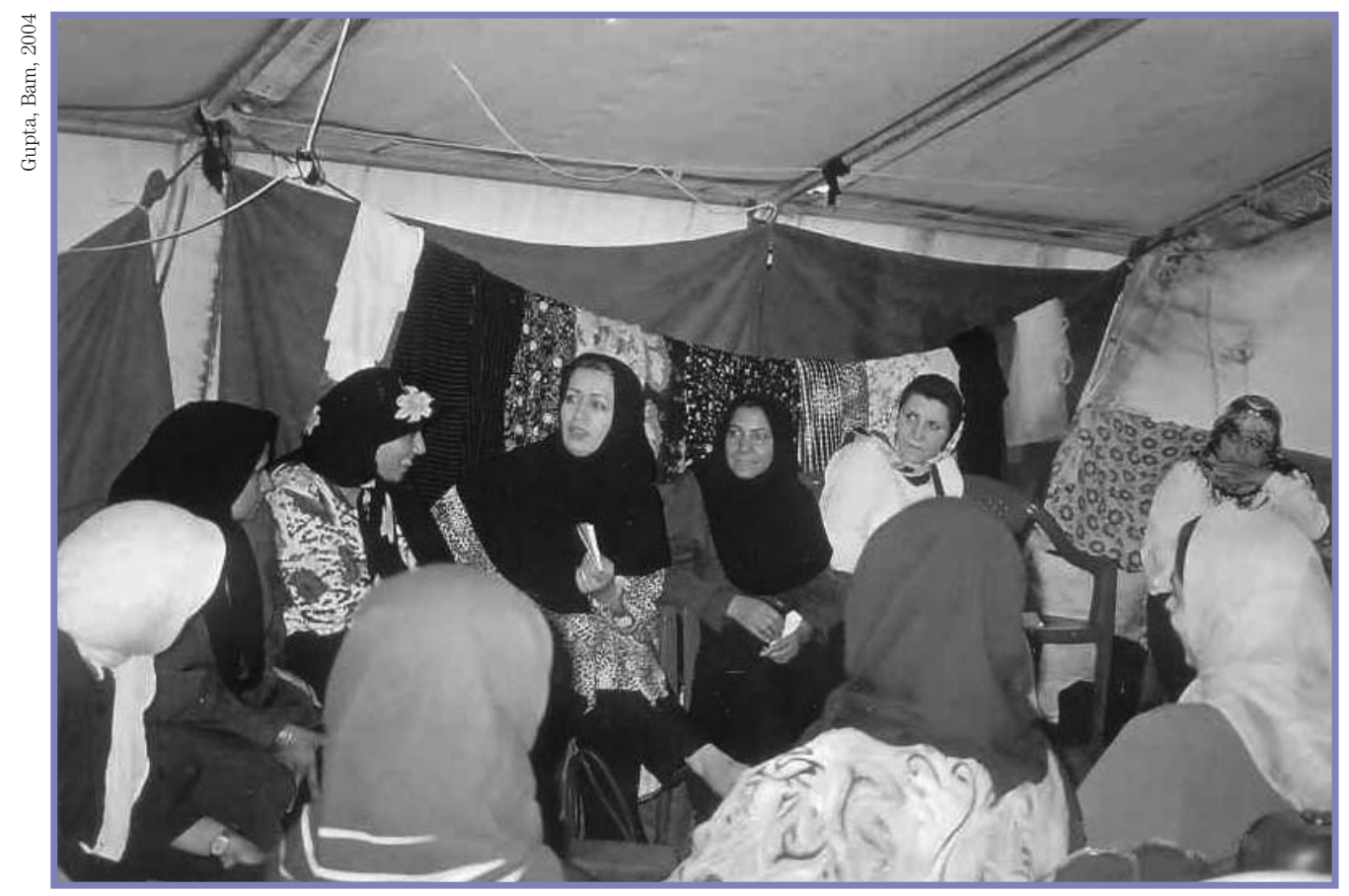

storing their communities in the relief and subsequent recovery processes. Four types of barriers are highlighted, some derived from the tension between emergency and development approaches and others related to biases about gender roles and professional expertise.

First, despite the lip service paid to disaster reduction and sustainable development, policymakers often fail to realize that postdisaster efforts are, in fact, development interventions that should reflect principles of participation and sustainability. Emergency, shortterm disaster-response programming favors technical responses that elevate the involvement of outside professionals over the priorities, skills, and knowledge of affected citizens. Standardized, topdown, bricks-and-mortar-type government programs ignore the complexity of communities' needs in rebuilding their lives and livelihoods.

Second, even when the importance of local communities' participation is recognized, often no clear agreement exists about what this participation should en- tail in relation to the roles of the government, international relief, and donor organizations. Lack of communication and coordination between the government agencies, aid organizations, and NGOs often wastes a sizeable share of the resources flowing into the affected area. International aid efforts, concentrated on emergency relief, frequently compounds the problem by fostering competition, dependency, and corruption among affected communities and civic groups trying to access this support.

Third, relief and subsequent recovery efforts fail to pay adequate attention to the gender-specific impacts of disasters. Disasters increase women's household and care-giving work dramatically for an extended period of time as housing and social infrastructure once destroyed is slowly replaced. They require women to manage displaced households and restore family livelihoods. Yet postdisaster aid efforts generally ignore this reality and target male-headed households as the primary claimants for government and other support. Not only does this 


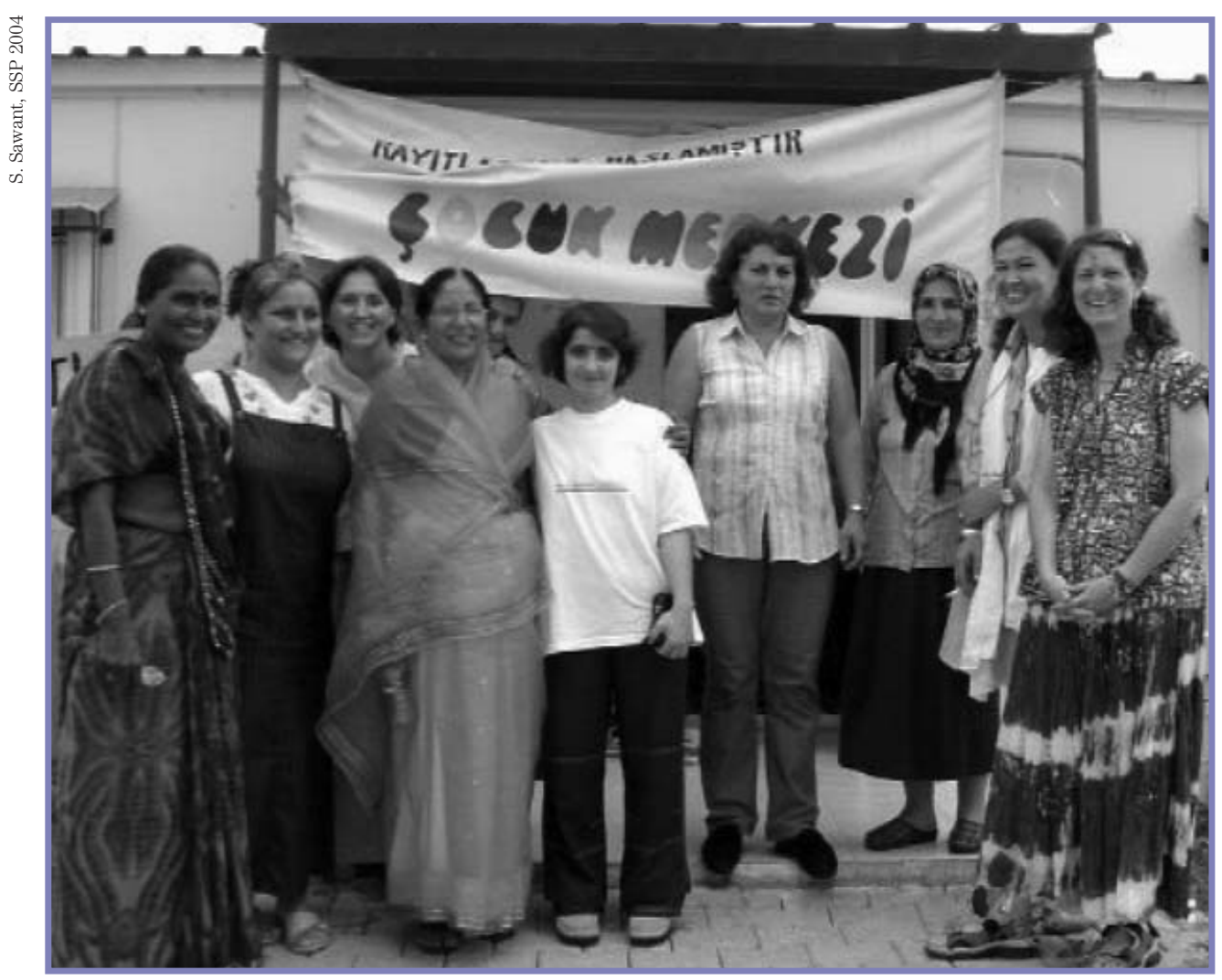

approach to aid ignore women's joint claim on family assets, it also ignores the needs of women living apart from maleheaded households and is largely indifferent to the income-generating roles that women do and must play. These biases substantially undermine prospects for household and community recovery. Gender-sensitive programming is essential during emergency relief. The central aim of disaster relief is to support and rebuild communities; what women do to keep their families and communities together in the critical moments after disaster occurs often is taken for granted. Protocols must be developed that value women's priorities and contributions appropriately.

Fourth, misconceptions are widespread about grassroots women's groups as small-scale, passive, and low-tech, despite considerable evidence to the contrary (Batliwala 2001). The case studies indicate that grassroots efforts can, if supported, rapidly mobilize a critical mass of actors. Women can acquire nontraditional skills and take on information-giving roles often considered to be the male domain, overcome male opposition and skepticism, and take on active leadership to rebuild their communities.

Reducing the economic vulnerability of women and of their families is a key mitigation measure that reduces potential losses from future disasters. A longterm development perspective is critical, starting at the relief stage, in the allocation and use of resources in order to foster self-reliance, build local capacity, and avoid dependency. Capturing momentum in the region early is important for integrating women's participation in postdisaster efforts. Lessons learned from the case studies shed light not only on obstacles but also on how women's involvement adds value and 
productivity to postdisaster investments (see Box 7). The lessons include a set of good practice principles that could redirect postdisaster programming toward gender-equitable, community-development opportunities. These principles include:

First, donors and international emergency aid agencies must broaden accountability measures for aid and loan granting to reward efforts that demonstrably reduce social vulnerabilities and foster participatory local development throughout the postdisaster relief and recovery stages. Guidelines to distribute resources more evenly across the stages of relief to recovery should include holding the powerful relief industry accountable. Moreover, distribution and procurement policies should encourage innovative and appropriate local approaches, taking special note of the piv- otal role that women's groups can play throughout the process of relief, recovery, and long-term development.

Second, as they recognize that poor women are among the most vulnerable and marginalized groups when disaster strikes, policy and program designers must establish specific monitoring mechanisms to ensure that women can access resources, participate publicly in planning and decisionmaking associated with postdisaster recovery, and organize themselves and build their capacities to sustain their involvement throughout the years of the recovery and development processes.

Third, the case studies suggest two cornerstones for good programming: creating formal spaces where women's groups can organize to participate in postdisaster efforts and formally allocating resources and roles to groups of af-

\section{Box 7}

\section{The Practical and Strategic Contributions of Affected Women to Disaster Response and Mitigation}

Women's groups are talented in gathering local information that is difficult, if not impossible for outsiders to access, and in monitoring the implementation of government programs. They can ensure proper allocation of resources by identifying those in need and exposing corruption.

Women's groups can collectively mobilize local resources and rebuild community networks to help restore and operate essential services, such as childcare, education, health, water, and explore new livelihood activities. Capacity building and financial support is crucial to support women develop collective and non-traditional livelihood strategies.

Grassroots women can function as intermediaries between their communities and the government in a manner that improves the speed, quality, and accountability of the government programs (as in the case of Maharashtra). When trained, they can effectively communicate information about earthquake safety, mitigation measures, and government programs, and resolve local conflicts as negotiators. This role not only helps affected families, but also increases the government's credibility in the eyes of local communities. An outcome of their active involvement is respect in the eyes of their communities and authorities, which starts changing gender stereotypes.

Women's groups can provide effective support and guidance to women from new disaster areas. 
fected women to ensure that they can: (1) access entitlements and assets in a manner that reduces their vulnerability and the prevailing gender and class/caste biases; (2) participate in government and donor planning processes in order to design social, livelihood, and housing support services that reduce the household and public work burden of poor women; (3) claim permanent community meeting spaces that they manage themselves; (4) collect and disseminate resources and information; (5) publicly establish, implement, and evaluate postdisaster relief-to-recovery plans and programs related to social, economic, and physical infrastructure and governance; (6) have equal access to formal platforms for ongoing dialogue, negotiations, and feedback; and (7) claim recognition for their accomplishments and knowledge, and in turn, be given the resources to enable them to advise their peers in other affected communities when similar disasters strike.

The case studies also suggest that institutional frameworks are crucial in helping to achieve the large-scale participation of women. The Maharashtra State government was persuaded to make formal spaces available for women's participation available in reconstruction efforts, and it supported long-term development efforts at the district level as well. Coupled with the Indian quota system for women's representation in village governments, and the existence of government antipoverty programs designed to help rural women, Maharashtran women's groups were able to organize effectively.

Finally, given the significant obstacles to applying a development and genderequity approach to postdisaster investments and programming, the case studies also imply that women's groups in affected communities (and supporting
NGOS) benefit from joining networks that connect their experience, publicly highlight their results, and link them to key institutions to advocate for policy and program change.

\section{References}

Batliwala, Srilatha. 2001. Remarks made at the Grassroots Women's International Academy at Habitat +5 , New York. <http://www. groots.org > . Accessed 5 January 2005.

British Broadcasting Corporation (BBC). 2005. World News 1/23/05.

Coskun, Zehra. 2001. KEDV advisory board member. Personal communication.

Davis, Mike. 1999. Ecology of Fear: Los Angeles and the Imagination of Disaster. New York: Vintage Books.

Delaney, Patricia L. and Elizabeth Shrader. 2000. "Gender and post-disaster reconstruction: The case of Hurricane Mitch in Honduras and Nicaragua." Decision review draft. Washington, DC: LCSPG/LAC Gender Team, The World Bank.

Enarson, Elaine. 2000. "Gender and Natural Disasters." Employment Working Paper 1. International Labor Organization (ILO) Recovery and Reconstruction Department, Geneva: ILO.

2004. "Making risky environments safer: Women building sustainable and disasterresilient communities." < http://www.un.org/ womenwatch/daw/public/w2000.html>. Accessed 24 August 2005.

Enarson, Elaine and Betty Hearn Morrow (eds.). 1998. The Gendered Terrain of Disaster: Through Women's Eyes. Westport, CT: Praeger.

Fothergill, A. 1998. "The neglect of gender in disaster work: An overview of the literature." In The Gendered Terrain of Disaster: Through Women's Eyes. Eds. Elaine Enarson and Betty Hearn Morrow. Westport, CT: Praeger.

Hewitt, Kenneth. 1998. "Excluded perspectives in the social construction of disaster." In What Is Disaster? Perspectives on the Question. Ed. E.I. Quanterelli. London: Routledge. 
International Federation of Red Cross (IFRC) and Red Crescent Societies. 2001. "Chapter 1: Relief, recovery and root causes." In World Disasters Report 2001. http://www. ifrc.org/publicat/wdr2001/chapter1.asp>. Geneva: IFRC. Accessed 1 August 2005.

Martin, Max. 2003. Women Builders: Breaking Barriers in Earthquake-torn Villages. Bangalore: Books for Change.

Parasuraman, S. and P.V. Unnikrishnan (eds.). 2000. India Disasters Report. New Delhi: Oxford University Press.

Swayam Shikshan Prayog (SSP). 2000a. "Worm's Eye View: Women's Information Centres." Available from http://www.sspindia.org. Unpublished.

2000b. "Small Change, Big Deals." Available from http://www.sspindia.org.

2002. Margin to Mainstream: Rebuilding Communities in Gujarat. <http:// www.sspindia.org/PDF\%20files/margin.pdf>. Accessed 1 August 2005.

United Nations Commission on Human Settlements. 2000. Habitat +5 Draft Report for Turkey. Unpublished.
2001. Press release \#CHS/00/01.

United Nations Economic Commission for Latin America and the Caribbean (UNECLAC). 2003. Handbook for Estimating the SocioEconomic and Environmental Effects of Disasters. Santiago, Chile: UNECLAC.

United Nations Inter-Agency Secretariat of the International Strategy for Disaster Reduction (UN/ISDR) and the UN Division for the Advancement of Women. 2001. "Environmental management and the mitigation of natural disasters: A gender perspective." Presentations and final report of the Expert Group Meeting in Ankara, Turkey, 1 November. <http://www.un.org/womenwatch/ daw/csw/env_manage/documents/EGMTurkey-final-report.pdf $>$. Accessed 1 August 2005.

World Bank Internal Evaluation Note. 2004. Disasters and Development: Learning from the World Bank's Experience. Washington, DC: World Bank.

World Bank Group. 2005. "Hazard risk management." <http://www.worldbank.org/hazards>. Accessed 1 August 2005. 


\section{SEEDS Advisory Committee}

Judith Bruce (Population Council)

Marilyn Carr (Consultant)

Marty Chen (Harvard University)

Monique Cohen (Microfinance Opportunities)

Caren Grown (Bard College, Levy Economics Institute)

Ann Leonard (Consultant)

Joyce Malombe (Institute of International Education)

Katharine McKee (USAID)

Aruna Rao (Gender at Work)

Mildred Warner (Cornell University)

Corinne Whitaker (International Women's Health Coalition)

Editor: Sandy Schilen

Editorial and Production Coordinator: Michelle Skaer

Copyeditor: Karen Tweedy-Holmes

Designer: Mike Vosika

Cover Photos: Front-Ayse Yonder, Izmit, 2000; Back-Ayse Yonder, Adapazari, 1999

\section{Other Editions of SEEDS Currently Available}

No. 2 Hanover Street: An Experiment to Train Women in Welding and Carpentry_Jamaica (English, Spanish)

No. 3 Market Women's Cooperatives: Giving Women Credit-Nicaragua (Spanish, French)

No. 4 Women and Handicrafts: Myth and Reality-International (English, Spanish, French)

No. 5 The Markala Cooperative: A New Approach to Traditional Economic Roles-Mali (French)

No. 6 The Working Women's Forum: Organizing for Credit and Change-India (French)

No. 7 Developing Non-Craft Employment for Women in Bangladesh (English, French, Spanish)

No. 8 Community Management of Waste Recycling: The SIRDO-Mexico (English, Spanish)

No. 9 The Women's Construction Collective: Building for the Future-Jamaica (English, Spanish)

No. 10 Forest Conservation in Nepal: Encouraging Women's Participation (English, Spanish, French, Nepali)

No. 11 Port Sudan Small Scale Enterprise Program-Sudan (English)
No. 12 The Muek-Lek Women's Dairy Project in Thailand (English)

No. 13 Child Care: Meeting the Needs of Working Mothers and Their Children (English, Spanish)

No. 14 Breaking New Ground: Reaching Out to Women Farmers in Western Zambia (English, Spanish, French)

No. 15 Self-Employment as a Means to Women's Economic Self-Sufficiency: Women Venture's Business Development Program (English)

No. 16 Wasteland Development and the Empowerment of Women: The SARTHI Experience (French, Hindi)

No. 17 Supporting Women Farmers in the Green Zones of Mozambique (English)

No. 18 Out of the Shadows: Homebased Workers Organize for International Recognition (English)

No. 19 Empowering the Next Generation: Girls of the Maqattam Garbage Settlement (English, Arabic)

No. 20 Women Street Vendors: The Road to Recognition (English)

No. 21 Are We Not Peasants Too? Land Rights and Women's Claims in India (English)

If you would like additional copies of this issue or any SEEDS issues listed above, send an e-mail to: seeds@popcouncil.org or seedseditor@gmail.com. Copies of selected SEEDS issues in local languages have been published by organizations in the following countries: Egypt, India, Indonesia, Kenya, Nepal, Pakistan, Thailand, and Vietnam. Please write to us for more information if you are interested in these materials. Most past editions of SEEDS are also available online at: www.popcouncil.org/publications. 
